WANL-TME-1202

\title{
NOTES OF MONTHLY DEVELOPMENT TEST PROGRAM REVIEW MEETING HELD WITH SNPO AT WANL ON JUNE 21, 1965
}

NOTICE

This report was prepared as an account of work This report was pred States Government. Neither sponsored by the United States Government States Energy the United States nor the United States Energy Research and Development Administration, nor any of their employees, nor any of their contractors, subcontractors, or their employees, makes any warranty, express or implied, or assumes any legal liability or responsibility for the accuracy, completeness liability or respons information, apparatus, product or process disclosed, or represents that its use would not infringe privately owned rights.
(Title Unclassified)

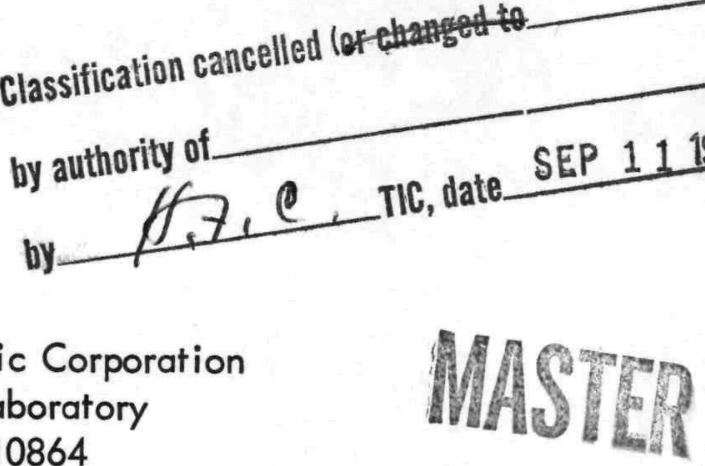

\section{Pittsburgh, Pennsylvania 15236}

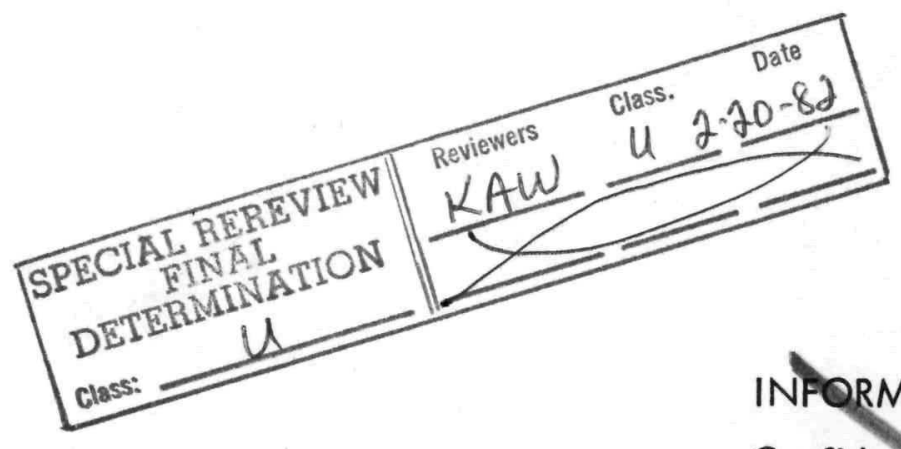

Confidential-Restricted Data
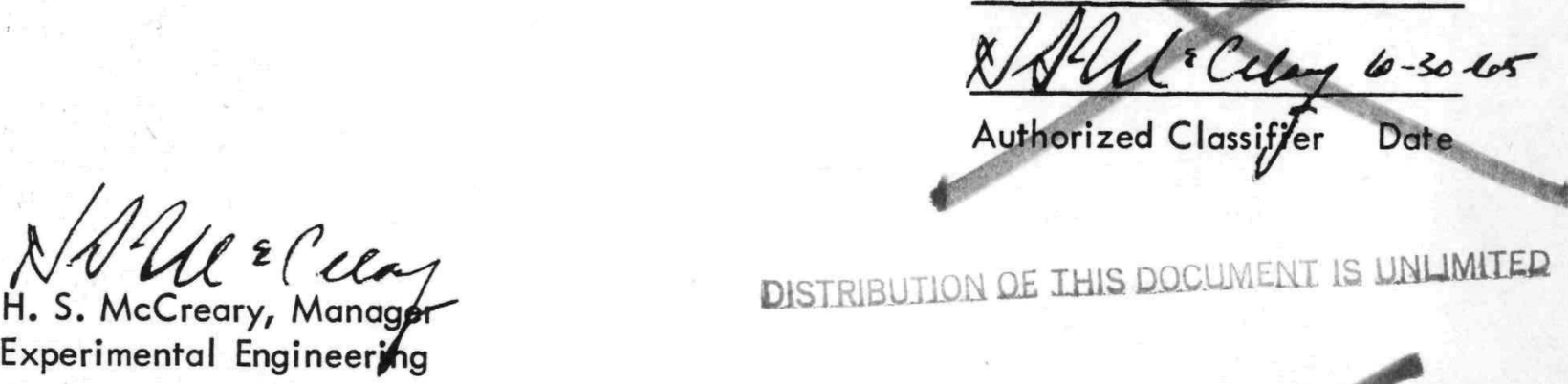

DISTRIBUTION OE IHIS DOCUMENT IS UNLIMITED

CONFIDENTIAL RESTRICTED DATAP Atomic Energy Act - 1954

\section{Group 1}

Excluded from Automatic Downgrading and Declassification 


\section{DISCLAIMER}

This report was prepared as an account of work sponsored by an agency of the United States Government. Neither the United States Government nor any agency Thereof, nor any of their employees, makes any warranty, express or implied, or assumes any legal liability or responsibility for the accuracy, completeness, or usefulness of any information, apparatus, product, or process disclosed, or represents that its use would not infringe privately owned rights. Reference herein to any specific commercial product, process, or service by trade name, trademark, manufacturer, or otherwise does not necessarily constitute or imply its endorsement, recommendation, or favoring by the United States Government or any agency thereof. The views and opinions of authors expressed herein do not necessarily state or reflect those of the United States Government or any agency thereof. 


\section{DISCLAIMER}

Portions of this document may be illegible in electronic image products. Images are produced from the best available original document. 
Notes of Monthly Development Test Program Review Meeting

$$
\text { held with SNPO at WANL on June 21, } 1965
$$

Attendees:

Bifano, N. J. DeZubay, E. A. Kalvin, G. Kanter, I. E. Kees, F. R. Larson, L.
WANL WANL SNPO-C WANL WANL AGC

Mader, G. Miller, D. F. Rowan, W. J. Watjen, E. Wisniewski, E.
AGC WANL WANL WANL WANL

Summaries of the present status of each Experimental Engineering Development Test were presented at the June 21, 1965, Monthly Development Test Program Review Meeting. The following material was presented by Engineering Mechanics:

$E M L-60$

\section{Core Effective Gap Tests}

The first test runs on this equipment were conducted during the past period. A thorough discussion of the equipment and the specific tests which were conducted was presented. The description of the equipment included a tour of the laboratory which permitted on-the-spot observation of the test fixtures, instrumentation, etc.

A knowledge of the behavior of the core diameter under various bundling pressures is necessary to estimate the average interelement gap size and the change in this gap size as bundling pressure varies. Tests are being performed to obtain data on the relationship between core diameter, bundling pressure, axial interelement flow characteristics, and fuel element porosity. The test rig is schematically shown in Figure 1. Results of the core diameter vs. bundling pressure tests are shown in Figure 2 . This decrease in diameter is substantiated 


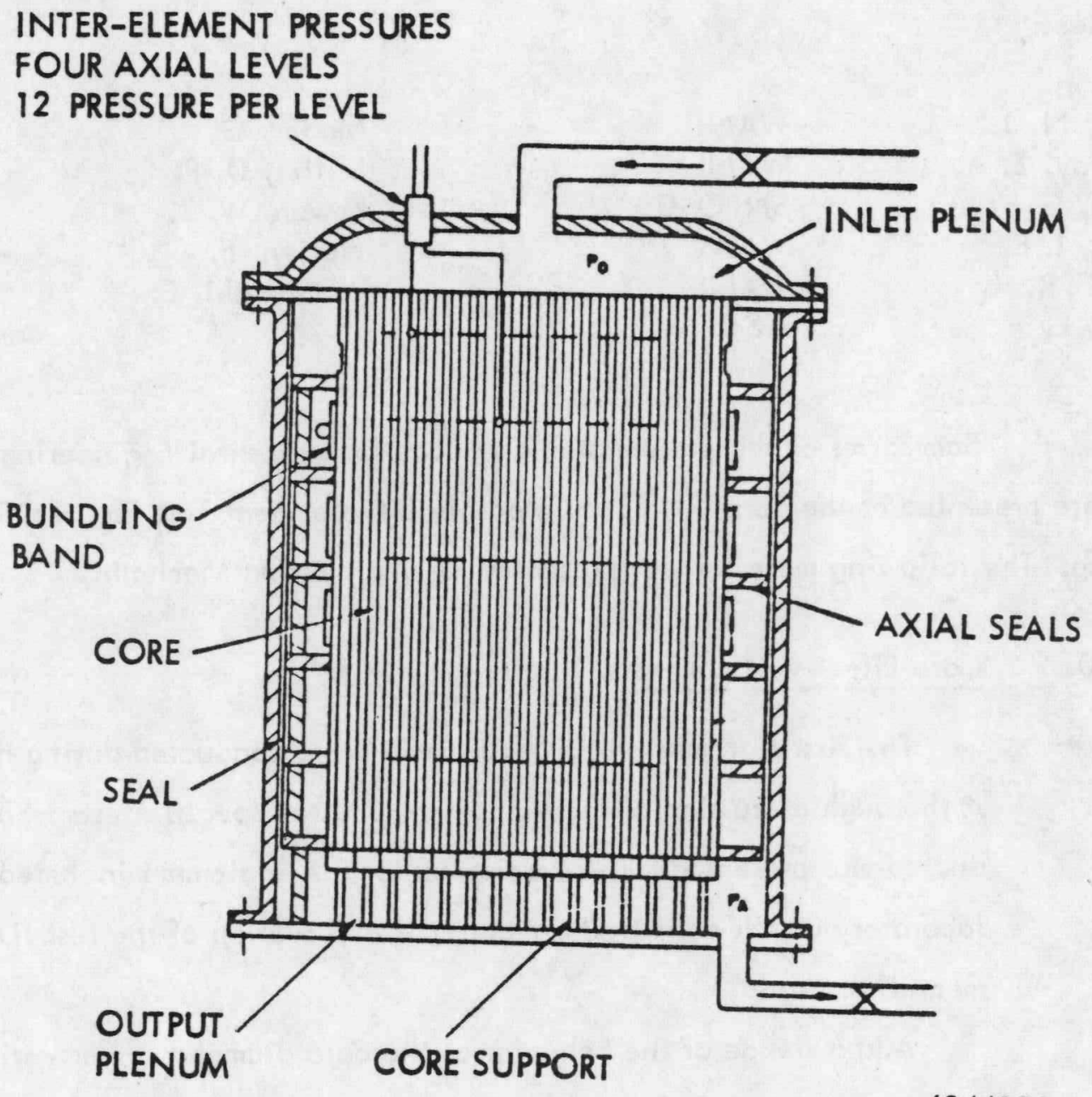

$604418 A$

Schematic of Test Fixture for Core Effective Gap Test

Figure 1 

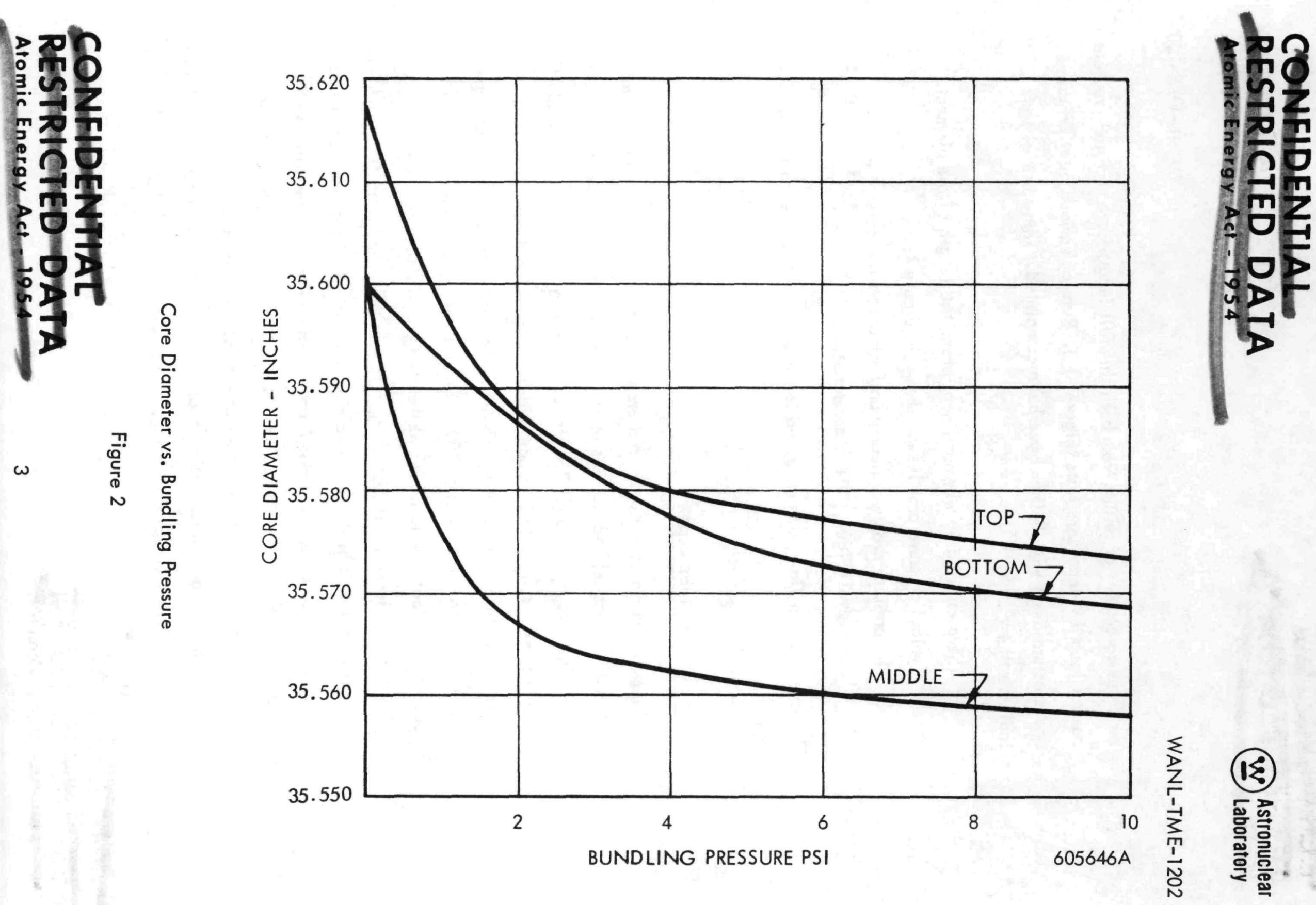
by close agreement of results from both this full length core test and previous partial length 9-inch core tests (Figure 3 ). Runs of various inlet pressures and pressure drops with helium have been completed. These initial tests indicate that:

1. The pressure drop was not linear along the length of the element. Typical pressure profiles are shown in Figure 4.

2. The pressure drop was nearly uniform across the core at each axial level (Figure 5 ) as expected.

The interelement flow rates measured in the tests to date are all shown in Figure 6.

EML-61 Tie Rod and Tie Tube Tests

The present status of the tie rod program is that $\mathrm{S}-\mathrm{N}$ curves have been completed on Inconel 718 tie rods at mean loads of $815 \mathrm{lbs}$. at room temperature. Fatigue tests of Inconel 750 tie rods were run at a mean load of $530 \mathrm{lbs}$. so that a comparison could be made with the Inconel 718 material. It appears that there are some fundamental differences in the behavior of the two types of materials, in that the Inconel 750 material appears to behave similarly to a Soderberg straight line relation, while the Inconel 718 range of stress diagram falls well below the Soderberg relationship. Some completely reversed stress tests on tie rods in flexure have been completed. These tests are being run to establish the combined stress relationship and to compare with WANL Materials Data Handbook information. The reversed flexure points obtained to date on 718 tie rods show a wide scatter indicating non-uniformity in this material with average values falling approximately 30 percent below the handbook data for the same type of loading. It can be concluded that the 718 


\section{CONFIDENTIAL \\ RESTRICTED DATA.}

(20) Astronuclear

Afomic Energy Act 1954

Laboratory

WANL-TME-1202

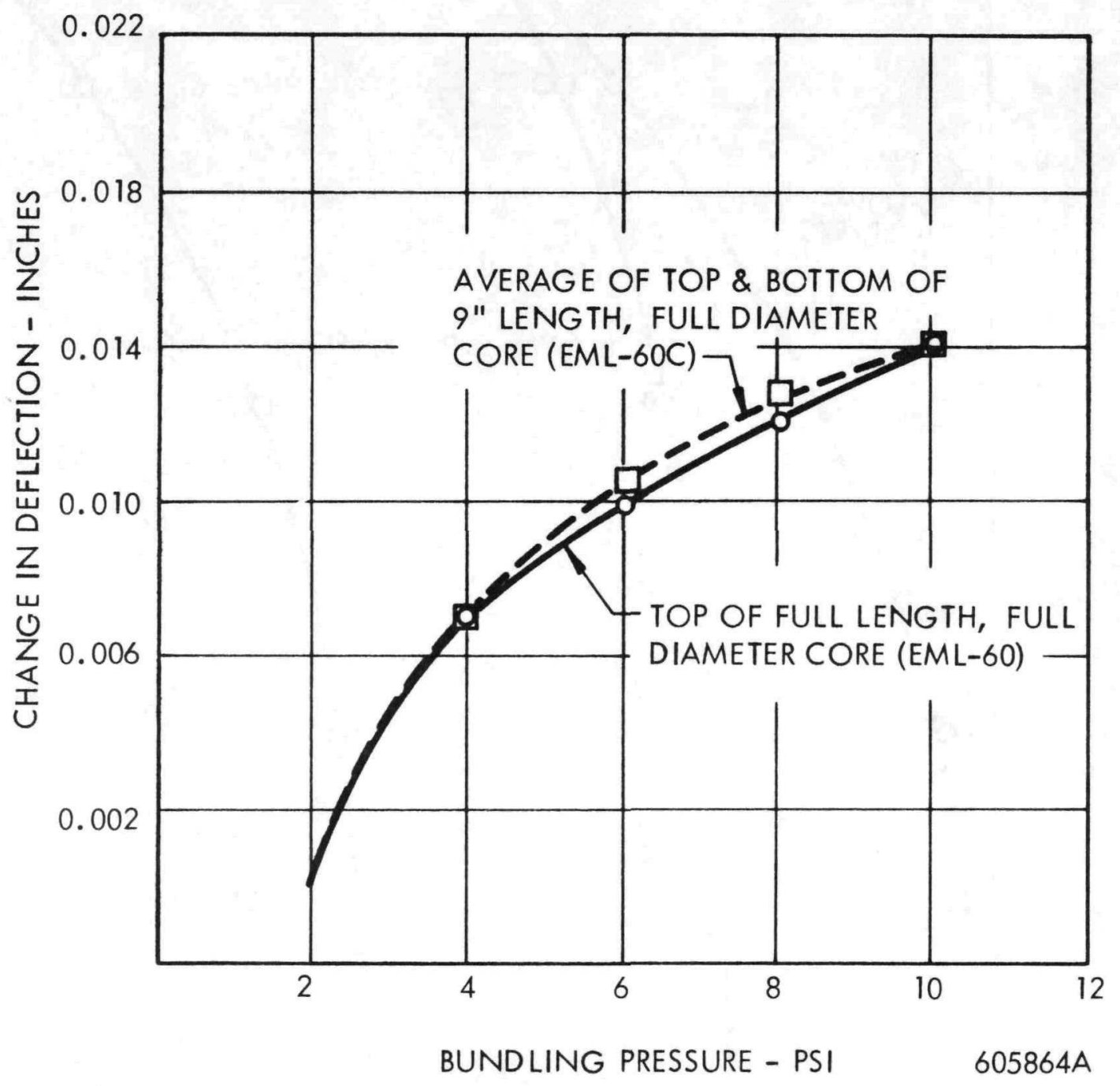

Change in Deflection vs. Bundling Pressure

Figure 3

\section{CONFIDENTHAL


WANL-TME-1202

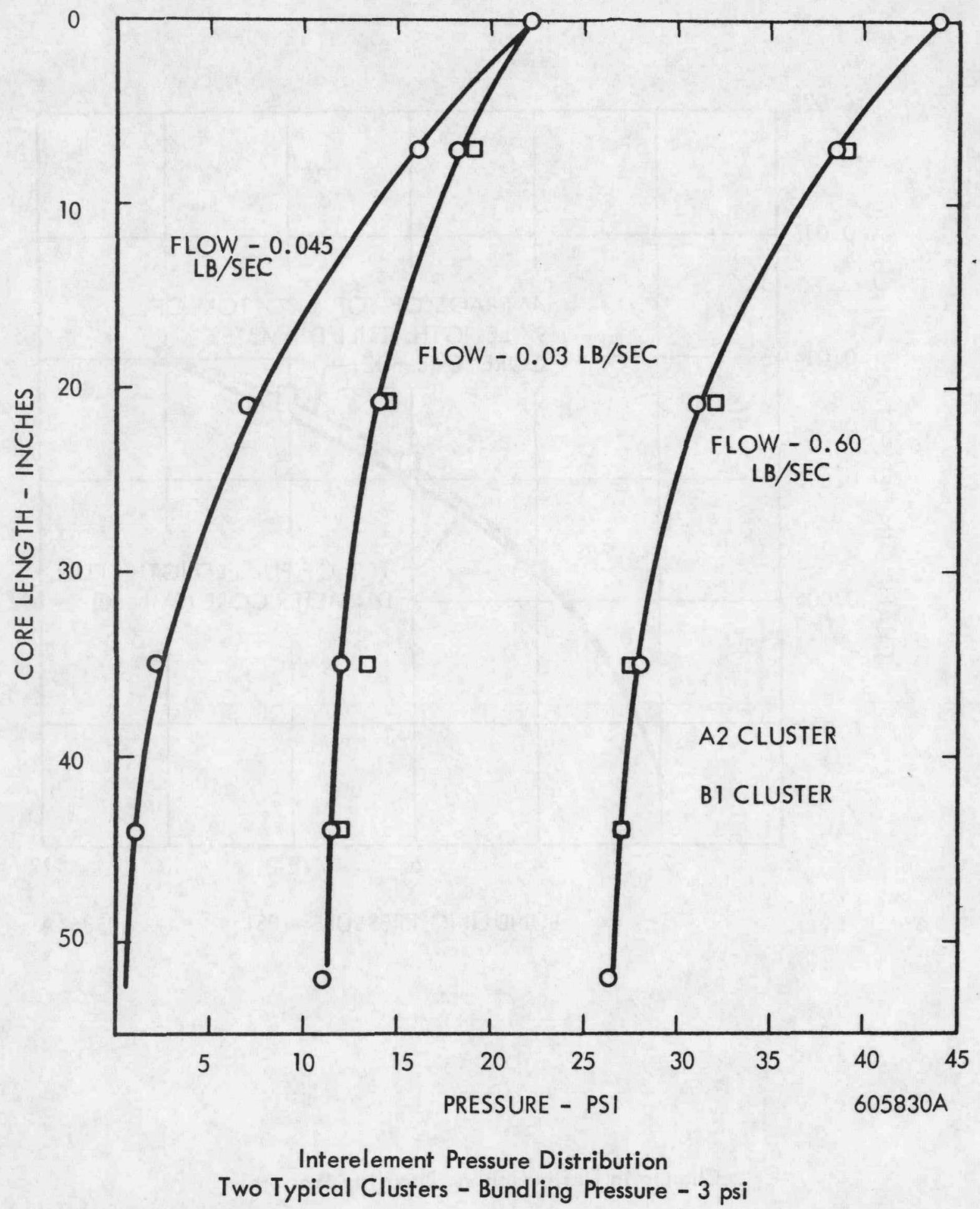

Figure 4 

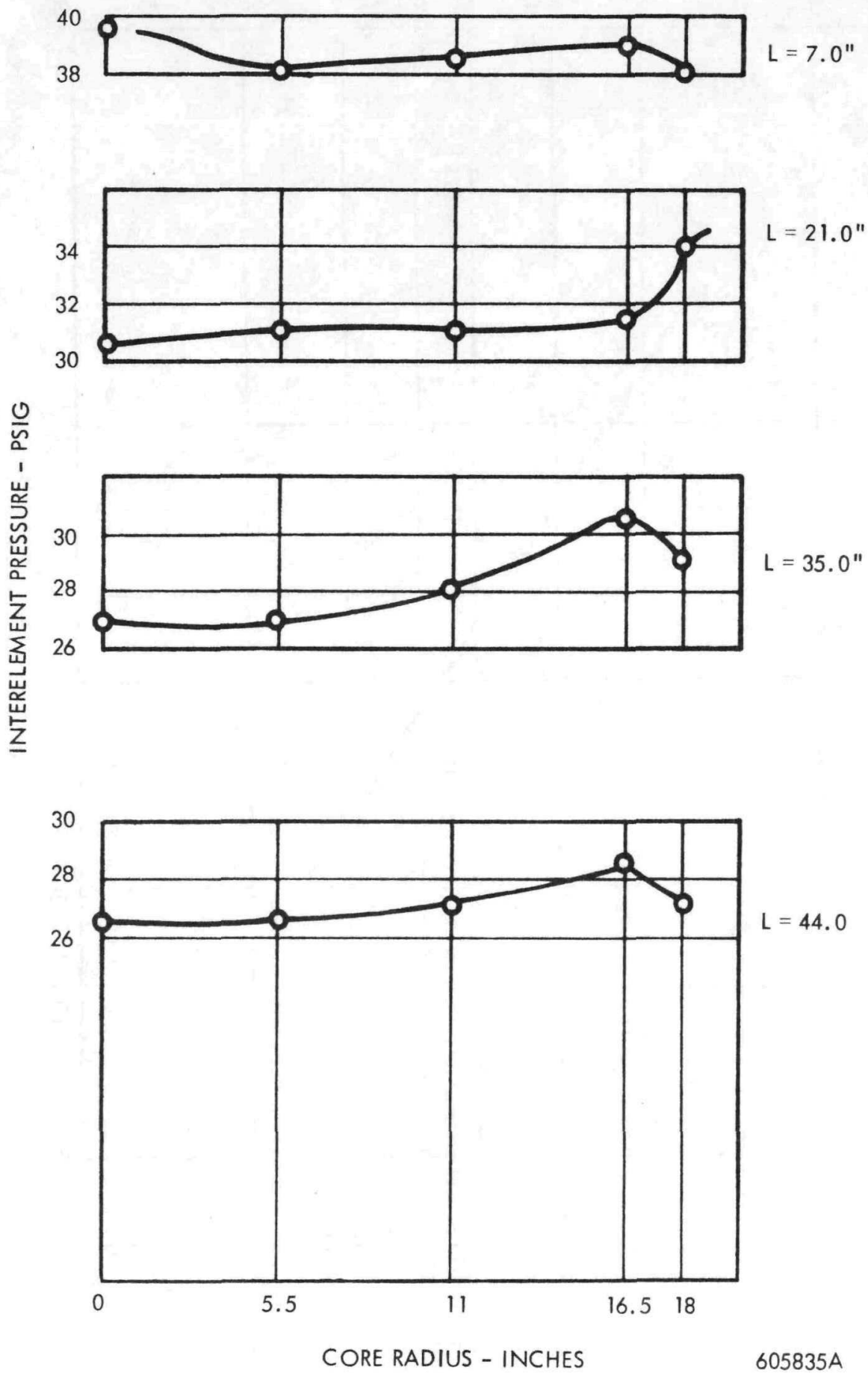

Radial Pressure Distribution

Figure 5 


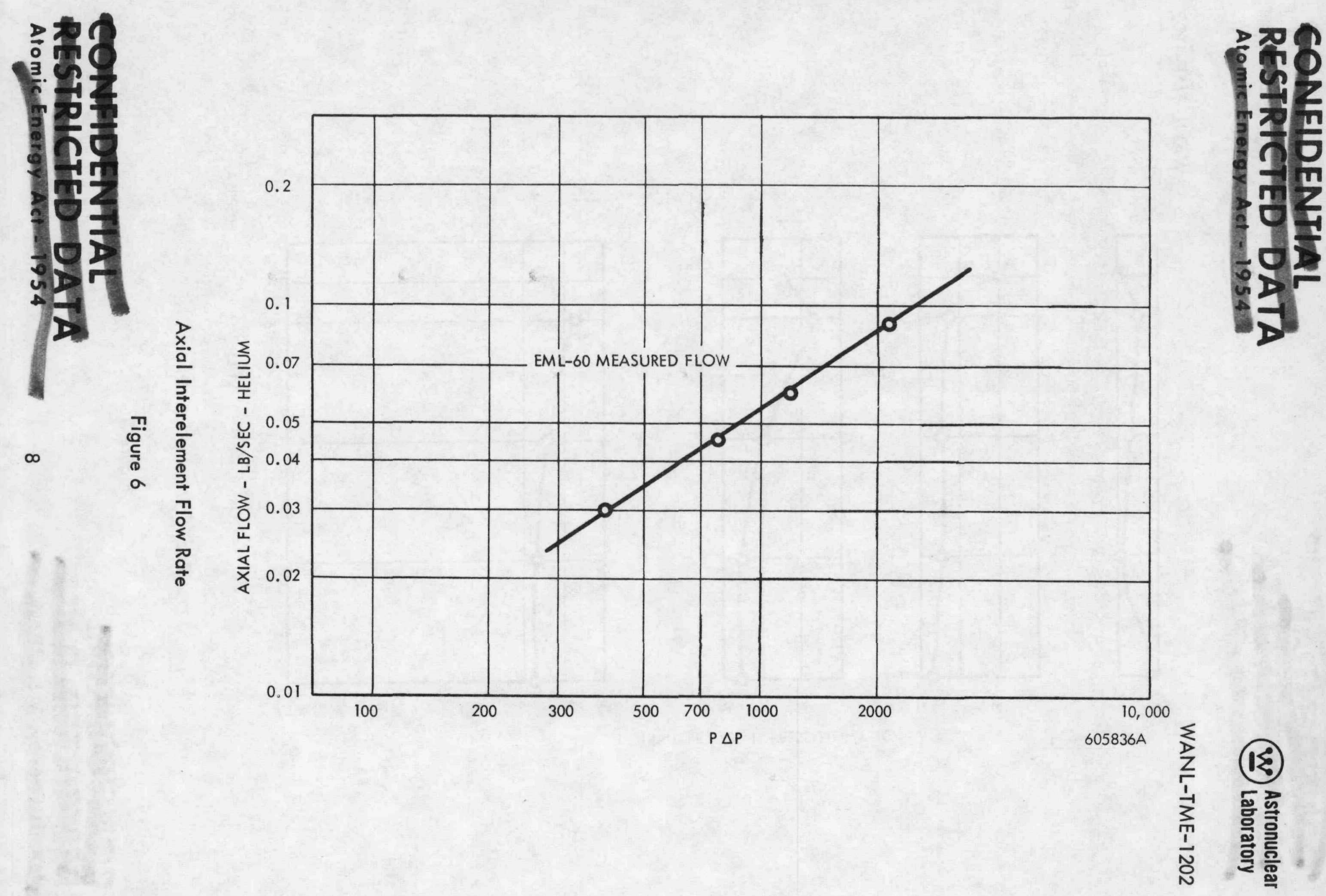


material does not possess the strength in fatigue that was originally anticipated. In fact, under reversed loading, the fatigue strength of the two materials are practically identical.

Tests were performed to evaluate the effect of flare geometry as a means of developing satisfactory advanced reactor tie tube designs. Static tests were completed on tie tube designs with $71 / 2^{\circ}, 15^{\circ}$, and $30^{\circ}$ flared ends. These tests were run using plugged flares, unplugged flares, and crimped type flare plugs. Both types of plugged flares ensured that failure always occurred in the tube itself. The unplugged $71 / 2^{\circ}$ flare pulled through the test fixture. When the flare was annealed, all three flare angles pulled through. Figure 7 is a photograph of the test specimens.

EML-65 Mechanical Tests of Instrumented NRX Reactor Components

Testing and calibration of NRX-A4 instrumented lateral support springs has been completed. Testing and calibration of NRX-A4 tie rods will commence upon their delivery to the Engineering Mechanics Laboratory.

EML-66 Fuel Element High Temperature Static and Fatigue Test

Compression testing of fueled elements specimens was continued with emphasis on higher temperature ranges of $4600^{\circ} R$ to $5000^{\circ} R$. The specimens tested were 2-inch long segments cut from fueled elements. The results indicated that a major transition in the mechanical properties of an element occurs above $4600^{\circ} \mathrm{R}$. Below this temperature, failures are brittle in nature while above this range the failure mode is plastic in nature. The average ultimate load of the fueled specimens drops from $4095 \mathrm{lbs}$. at $4800^{\circ} \mathrm{R}$ to 2700 lbs. at $5000^{\circ}$. 


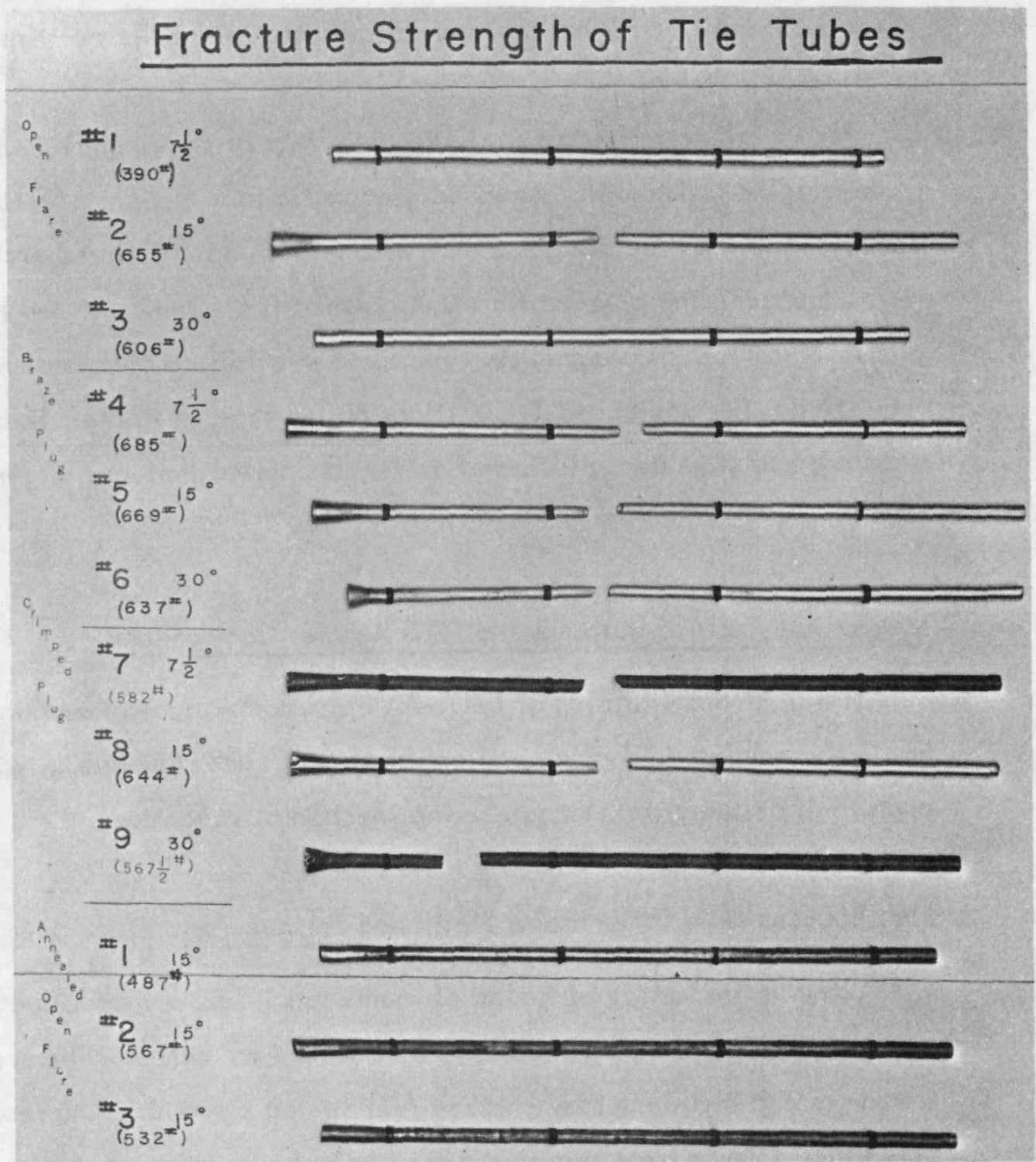

Fracture Strength of Tie Tubes

Figure 7 
Transient temperature tests were conducted to simulate the transient temperature conditions that occurred in the NRX-A3 core after the turbo-pump cutoff. These transient temperature tests represented a significant addition to the existing test program and provided confidence in the restart and running capability of the NRX-A3 reactor. Tests consisted of bringing the furnace up to temperature while maintaining a helium flow through the tube liner. This flow of gas was effective in maintaining a liner temperature between $1000^{\circ} \mathrm{R}$ and $1200^{\circ} \mathrm{R}$. The center element was brought to a surface temperature of $3800^{\circ} \mathrm{R}$ to obtain the desired transient response. Flow through the liner was abruptly turned off and the liner and exhaust gas temperatures monitored. When the desired thermal transient had been observed, flow was resumed and the liner brought to normal limits. The transient temperatures peaked at $2695^{\circ} \mathrm{R}$ and exceeded the eutectic temperature of $2460^{\circ} \mathrm{R}$ as seen in the A-3 reactor. The test results indicated that the liner can withstand thermal transients as high as $2695^{\circ} \mathrm{R}$ without melting or undue formation of carbides.

Several additional temperature tests were conducted on central element assemblies containing tie rod, liner tube and insulating sleeve. The specimens were heated by a quartz lamp furnace rated at $42 \mathrm{KW}$. The test results were as follows:

1. The liner tubes with the NRX-A3 type of thermocouple installation survived the test up to temperatures of $2650^{\circ} \mathrm{R}$.

2. Temperature gradient data was obtained which can be used as a basis for future thermal calculations for these components.

3. When graphite cement was used to attach the thermocouple to the liner tube, the melting point was lower and the tube melted in this area at approximately $2400^{\circ} \mathrm{R}$.

\section{CONFIDENTHAL}


EML-68 Core Insulation Development Testing

The core insulation program was set up to measure the amount of tile bowing that results from thermal gradients across the tile. This bowing is naturally affected by the core bundling pressure and has, therefore, been difficult to calculate. The test setup shown in Figure 8 includes provisions for varying the bundling pressure and for measuring the amount of tile bow under known thermal gradients. Figure 9 is a view of the internal components showing the water cooling lines, instrumentation leads and the heating element. Figure 10 shows the heater assembly, placement of tiles, filler strips, and copper parts that were used as a heat sink. The linear displacement transducer at the bottom was used to measure the total tile bow. Figure 10 also shows the pressure pistons used to apply bundling pressure. In operation, tile bow is measured by pressurizing the pistons while simultaneously measuring the total deflection of the tile. The bundling pressure was varied from 4 psi to 48 psi for each temperature gradient obtained. The results are plotted in Figure 11 and Figure 12 and illustrate that the data is in good agreement with calculated values for a $3140^{\circ}$ gradient.

A new insulating design consisting of 10 layers of .010 pyrofoil was tested to determine its insulating properties. The test results indicate close agreement with previous measurements on pyrotile when corrected for differences in thickness. 


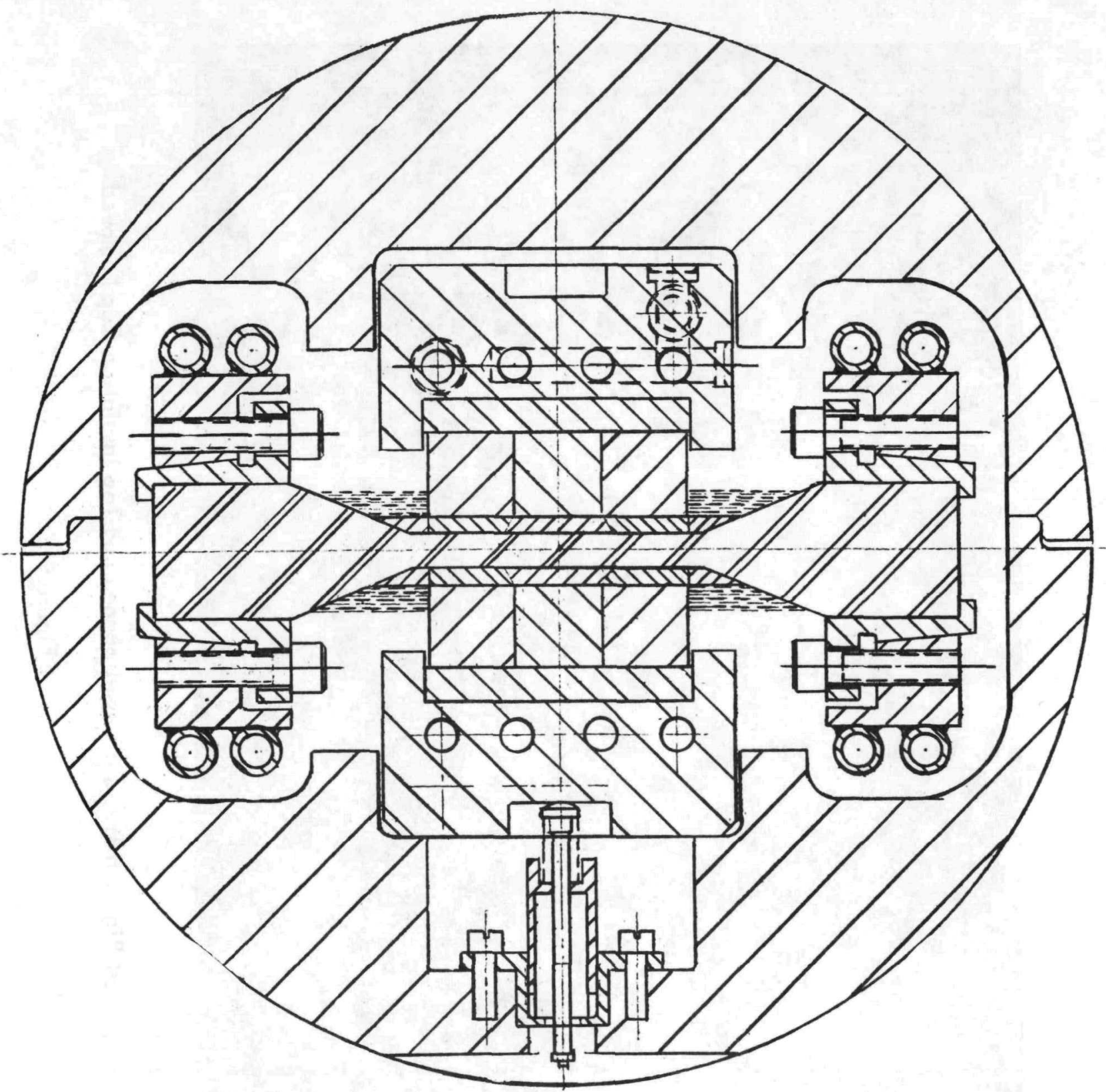

Cross Section of Test Rig

Figure 8 


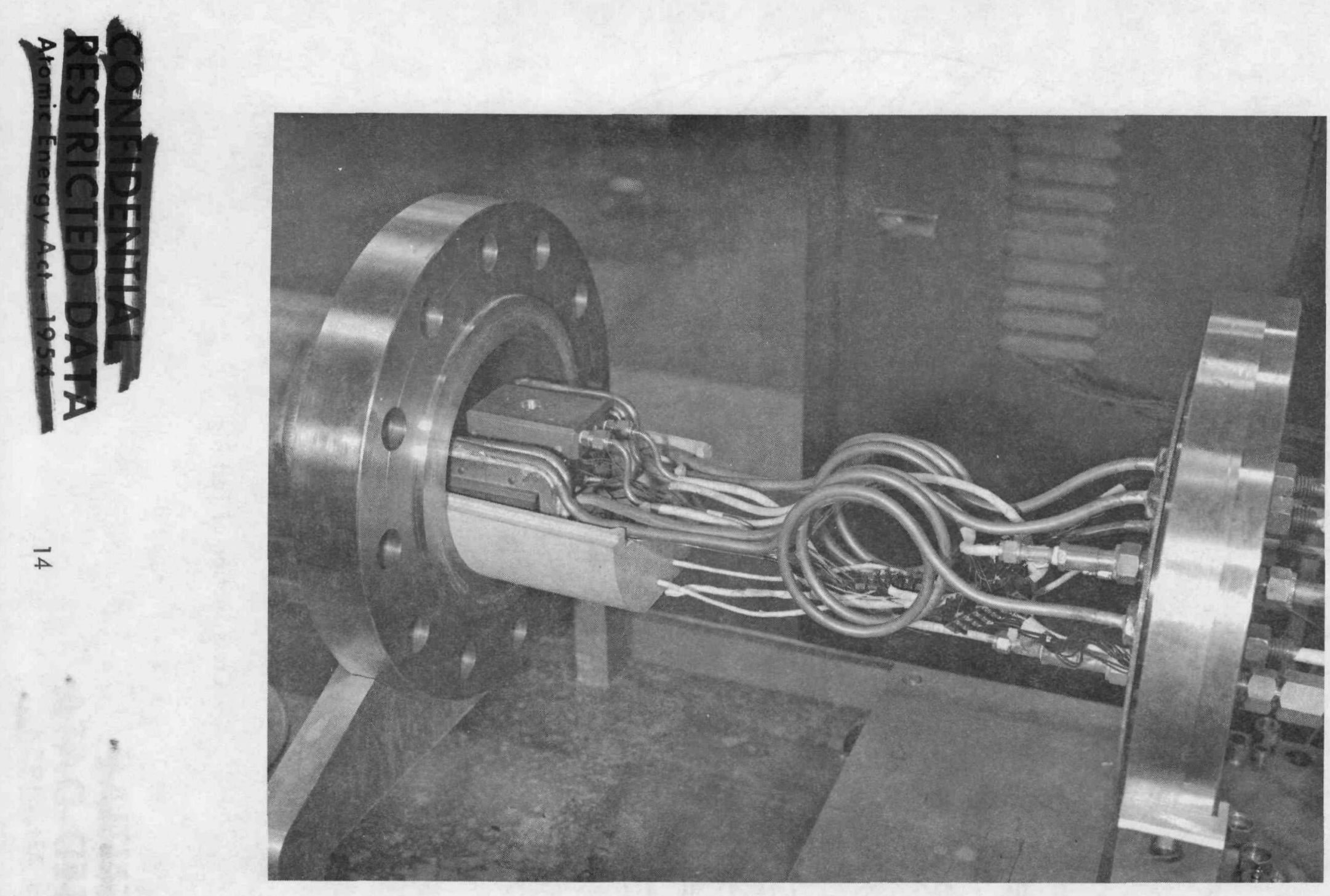

Test Rig with Pressure Vessel opened and Top Insulation Cap Removed

Figure 9

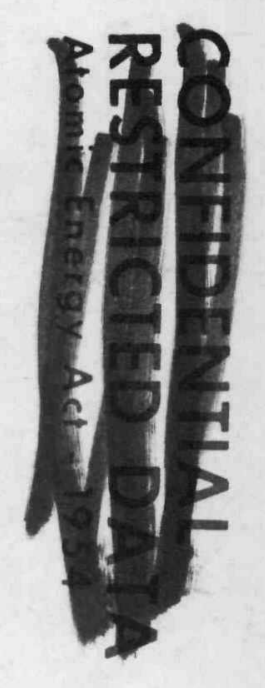

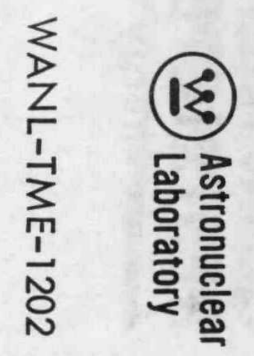




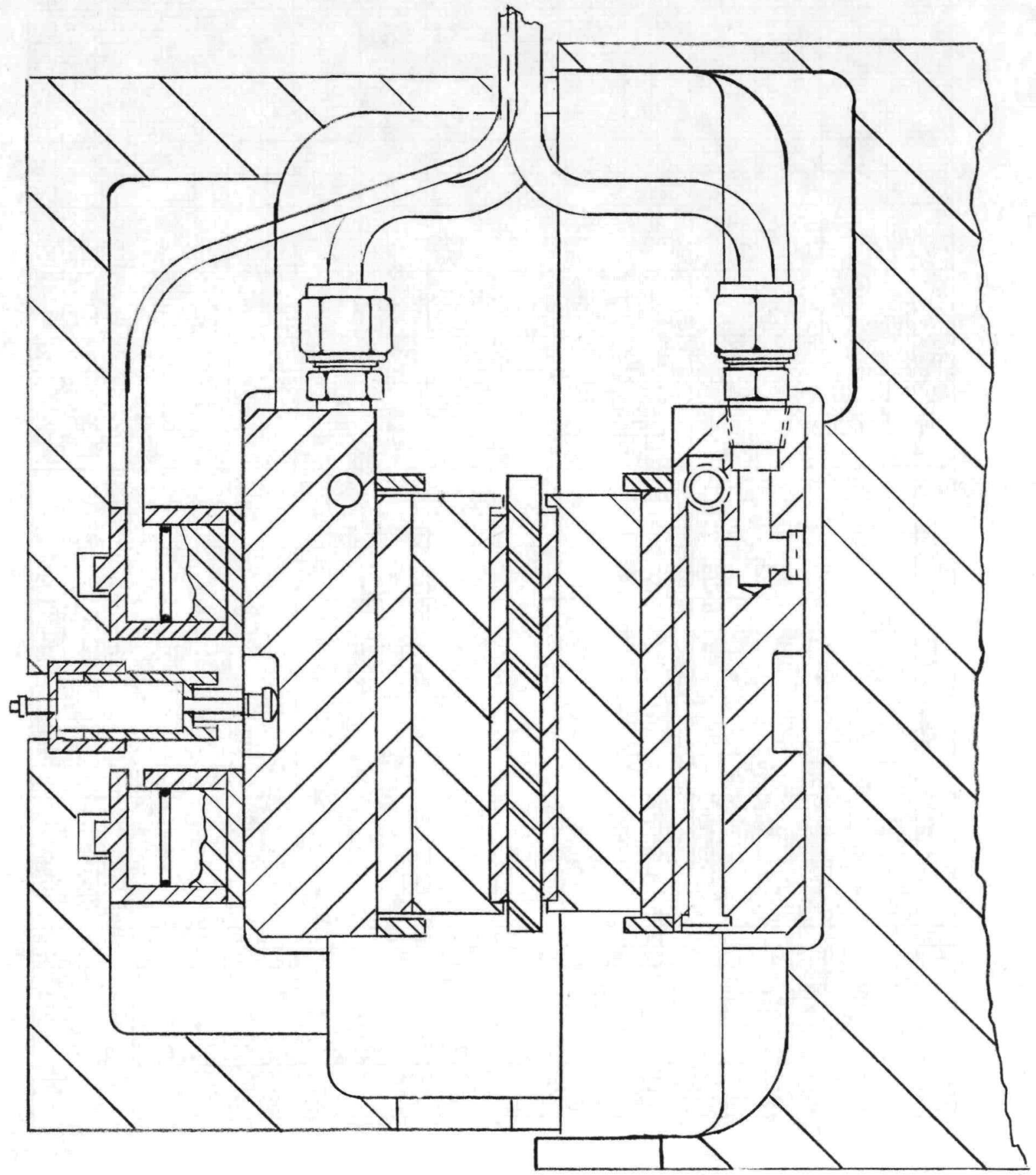

Cross Section of Test Rig

Figure 10

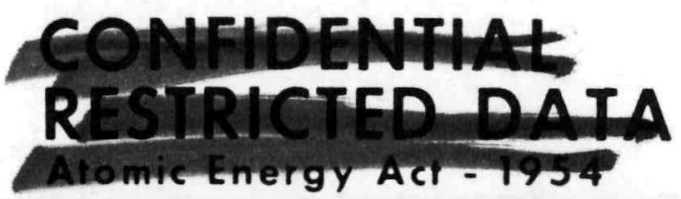




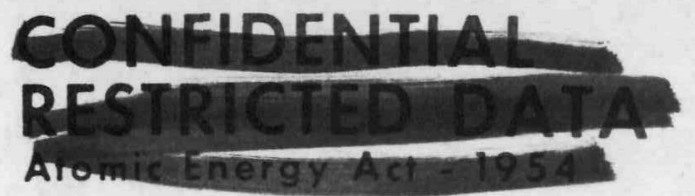

(20) Astronuclear

WANL-TME-1202

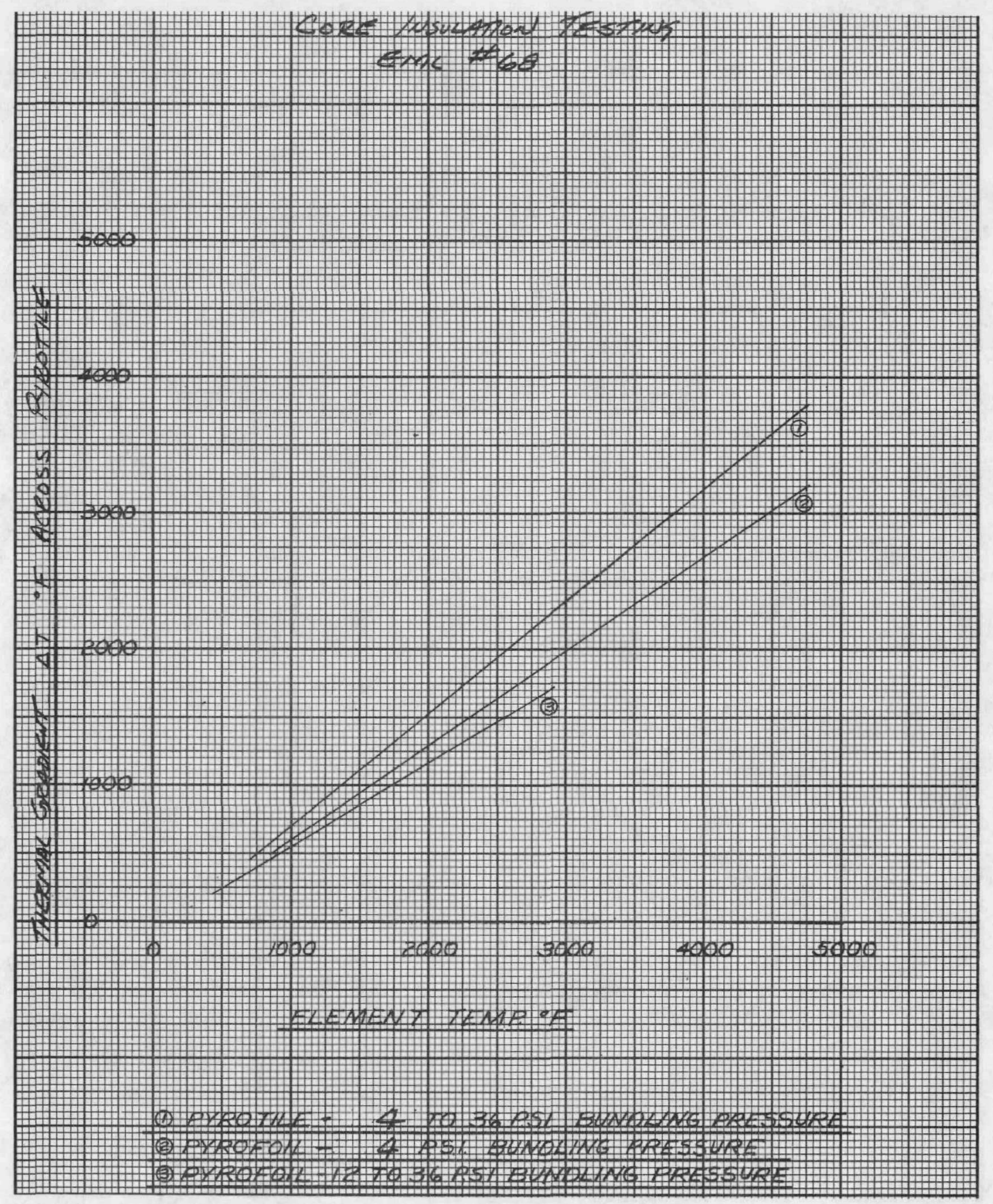

Core Insulation Testing

Figure 11
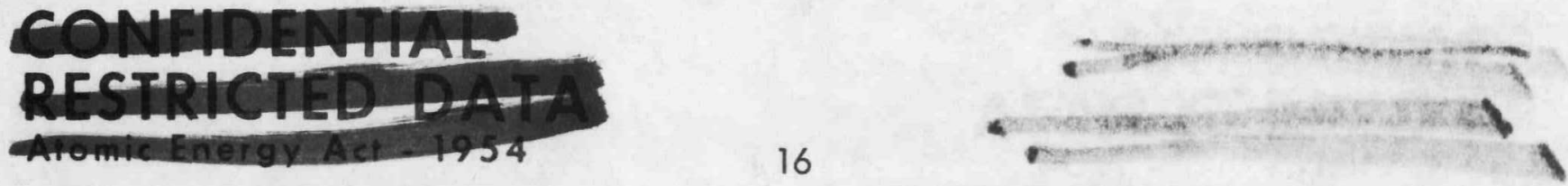
WANL-TME-1202

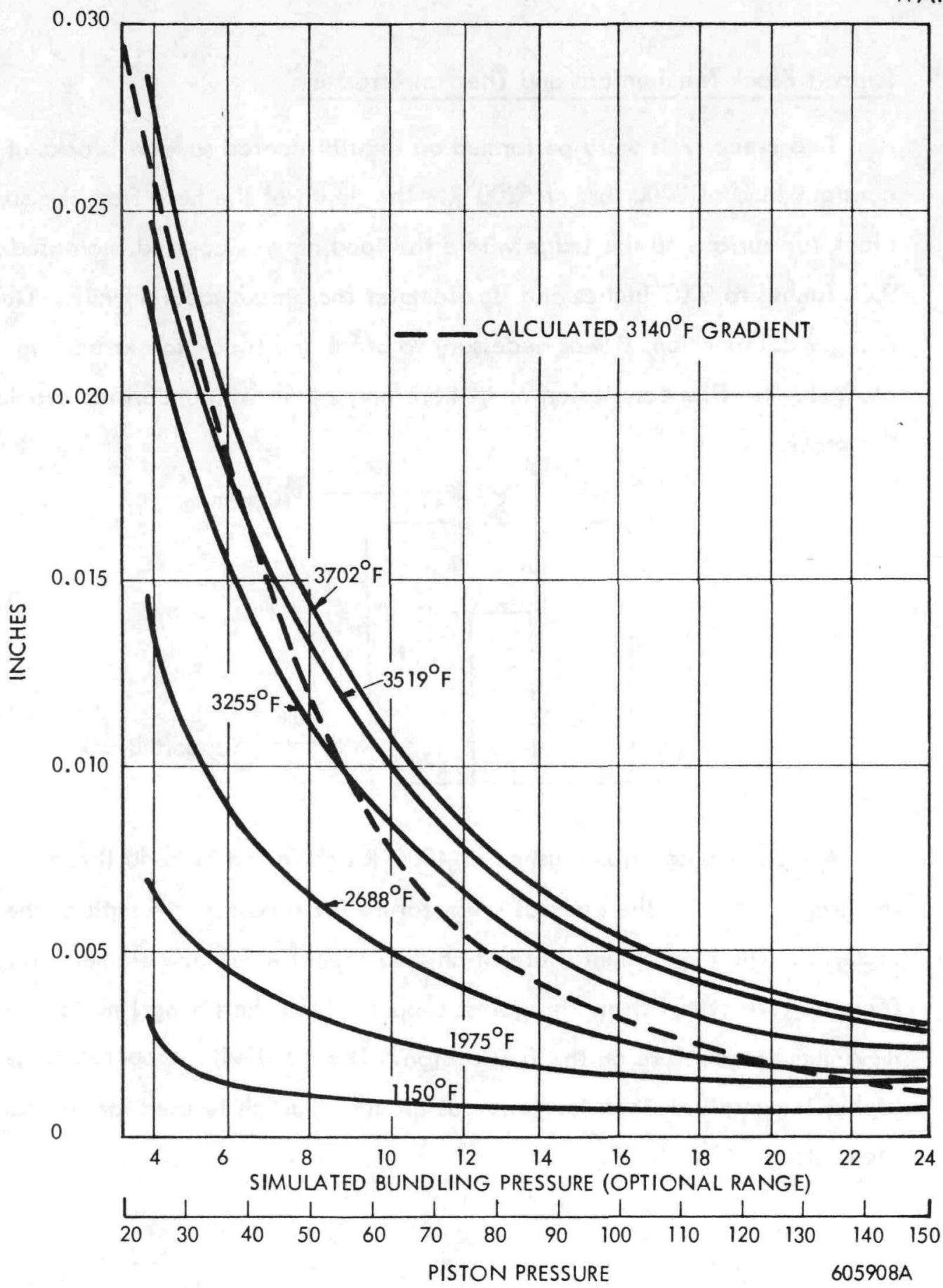

Pyrotile Bow vs. Core Bundling Pressure at Various Thermal Gradients

Figure 12

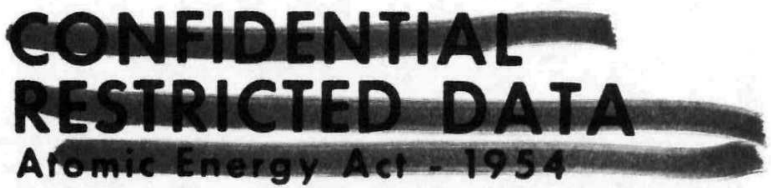



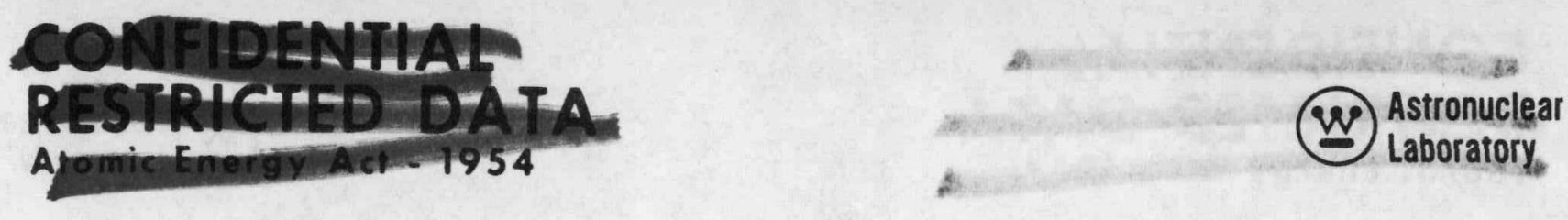

WANL-TME-1202

EML-69 Support Block Mechanical and Thermal Stresses

Two creep tests were performed on regular coated support blocks at a constant load of 3000 lbs. at $5200^{\circ}$. The depth of the hole from the support block top surface to the ledge where the loading was applied increased from 0.06 inches to 0.08 inches and its diameter increased about 11 mils. Due to plunger deformation, it was necessary to break the block to extract the plunger. No firm conclusion can, therefore, be drawn concerning cracks in the block.

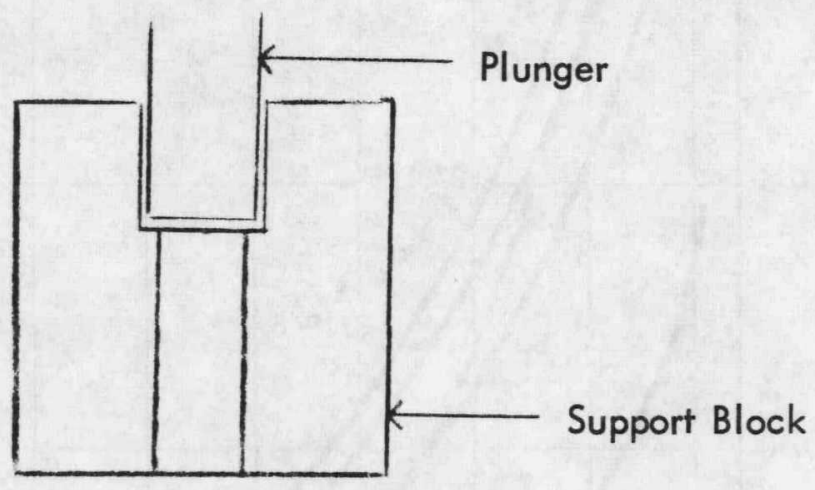

A support block was crushed at $4800^{\circ} \mathrm{R}$ and failed at 8840 lbs. as part of the program to find the peak of temperature for maximum strength of the material. The experimental use of an ATJ graphite furnace element to obtain increased structural strength against support block shattering limited the maximum temperature on the first design. The resistivity appeared larger at higher temperatures than the previous grades of graphite used for furnace elements. 
Strip Supported Cluster Test

This effort has been concentrated on test components for development of two new cluster designs. These designs are proposed as a means of eliminating the support block and reducing the effect of corrosion on core structural integrity. The lower design pictured in Figure 13 has a conventional tie rod that sits on the end of the center element. The keys at the top of the cluster are $60^{\circ}$ sectors of the center element and are bonded to the fueled elements. An offset is included to add strength to the design. The element load is transmitted through the keys through the center element and then to the tie rod. The upper design pictured in Figure 13 is similar except that a short tie rod is used to eliminate much of the center element hardware and put all of the cluster support structure at the cold end of the core. Both designs use common key supports and interlocking pins at the hot ends. The interlocking pins are included as a safety device to prevent an element from being ejected in the event of failure of a key. The main objectives of the test were:

1. To determine the strength of three candidate offsets under $10 \mathrm{psi}$ bundling pressure. The offsets tests were $0.01,0.015$, and 0.150 inches.

2. Determine the strength of keyed elements with no adhesive, epoxy $\mathrm{C}-2, \mathrm{P} 514$, and brazing alloy.

3. Determine the strength of various thread sizes and fits in the center element and the effect of thread engagement.

4. Determine the ability of the interlocking pin design to prevent relative movement between elements.

The basic offset was tested first without cement to determine the strength and mode of failure at 10 psi bundling pressure. The results averaged as follows:

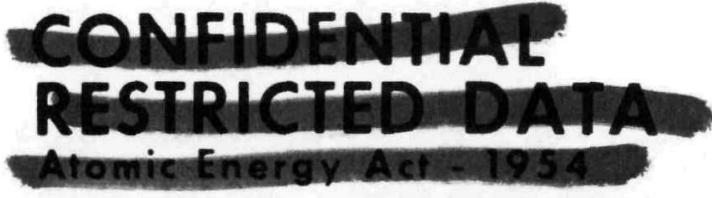




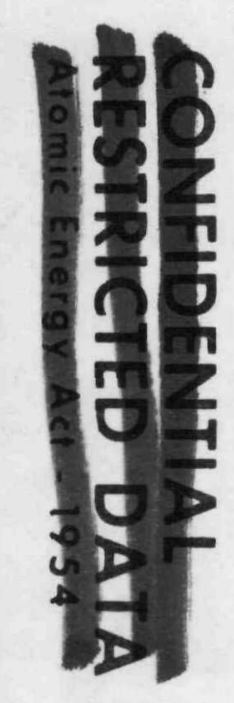

N $\quad \frac{7 n}{0}$

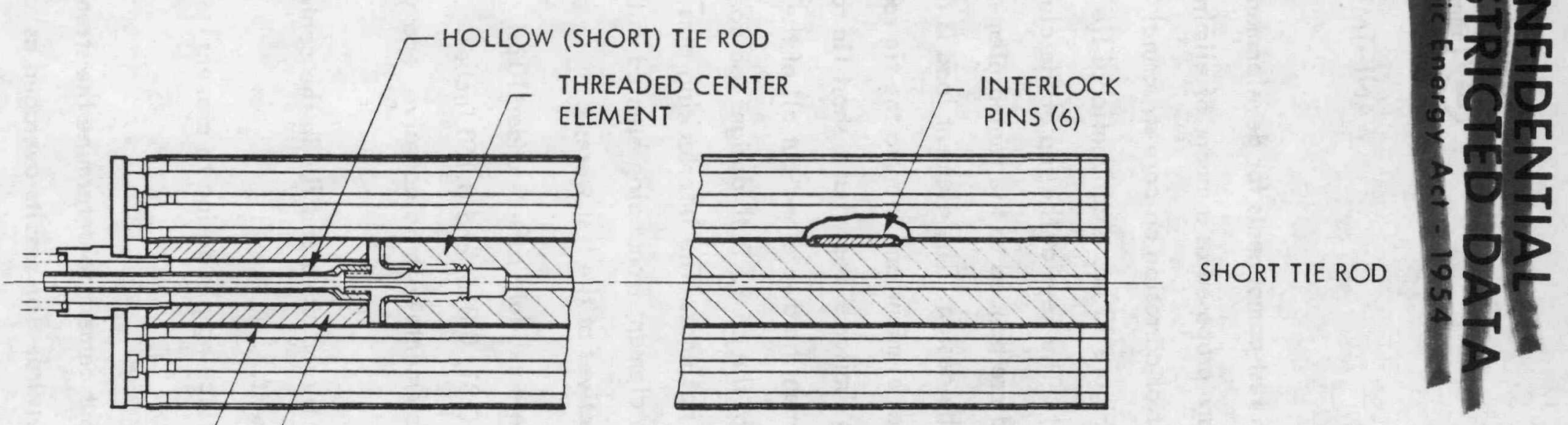

PROPOSED ELEMENT SUPPORT SYSTEM

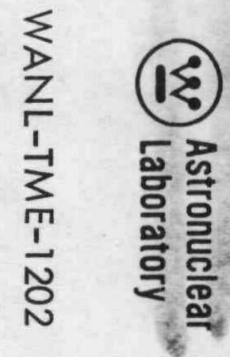


Offset

0.010

0.015

0.150
Average Failure Load

37 lbs.

64 lbs.

438 lbs.

The mode of failure for all keys was that the edge of the offset sheared at a $45^{\circ}$ angle permitting the key to move with respect to the element.

Based on these early tests, the 0.015 offset was preferred because of its higher failure load and because it did not present the fabrication and shearing problem associated with the 0.150 key.

Only the 0.010 and the 0.015 specimens were cemented with epoxy C-2 and tested. These tests showed that the 0.01 key could be loaded to an average of $581 \mathrm{lbs}$. and 0.015 key to an average of $586 \mathrm{lbs}$. before failure. The mode of failure began at the loaded end of the key with cracking through the key and the element at a $45^{\circ}$ angle.

Several 0.015 offsets were cemented with P514 and similarly tested. The results showed a wider degree of scatter than those keys cemented with epoxy, but the best results were comparable to the epoxy cemented keys. The mode of failure was similar to epoxy failures. In some instances, delamination of the keys occurred at the bond line with no failure of the key or the element.(Fig. 14) Close control of manufacturing process and rigid quality control inspections would, therefore, be required to ensure minimum load requirements would be met.

Testing of brazed keys has just begun since the development of techniques for evaluation of alloys has constituted a separate program of materials testing. On the basis of the limited tests conducted to date, this method holds the most promise for strength of the joint and consistency of results. The results have shown that the joint is stronger than the parent graphite and all failures have been through the key or the element. 


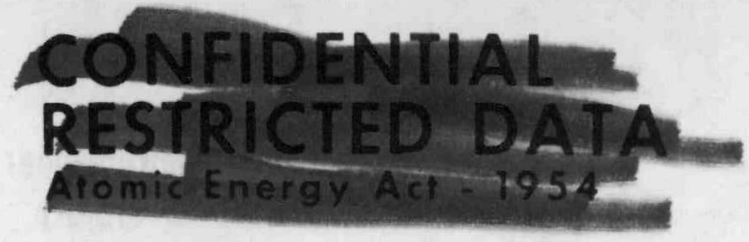
(W. Astronuclear

WANL-TME-1202

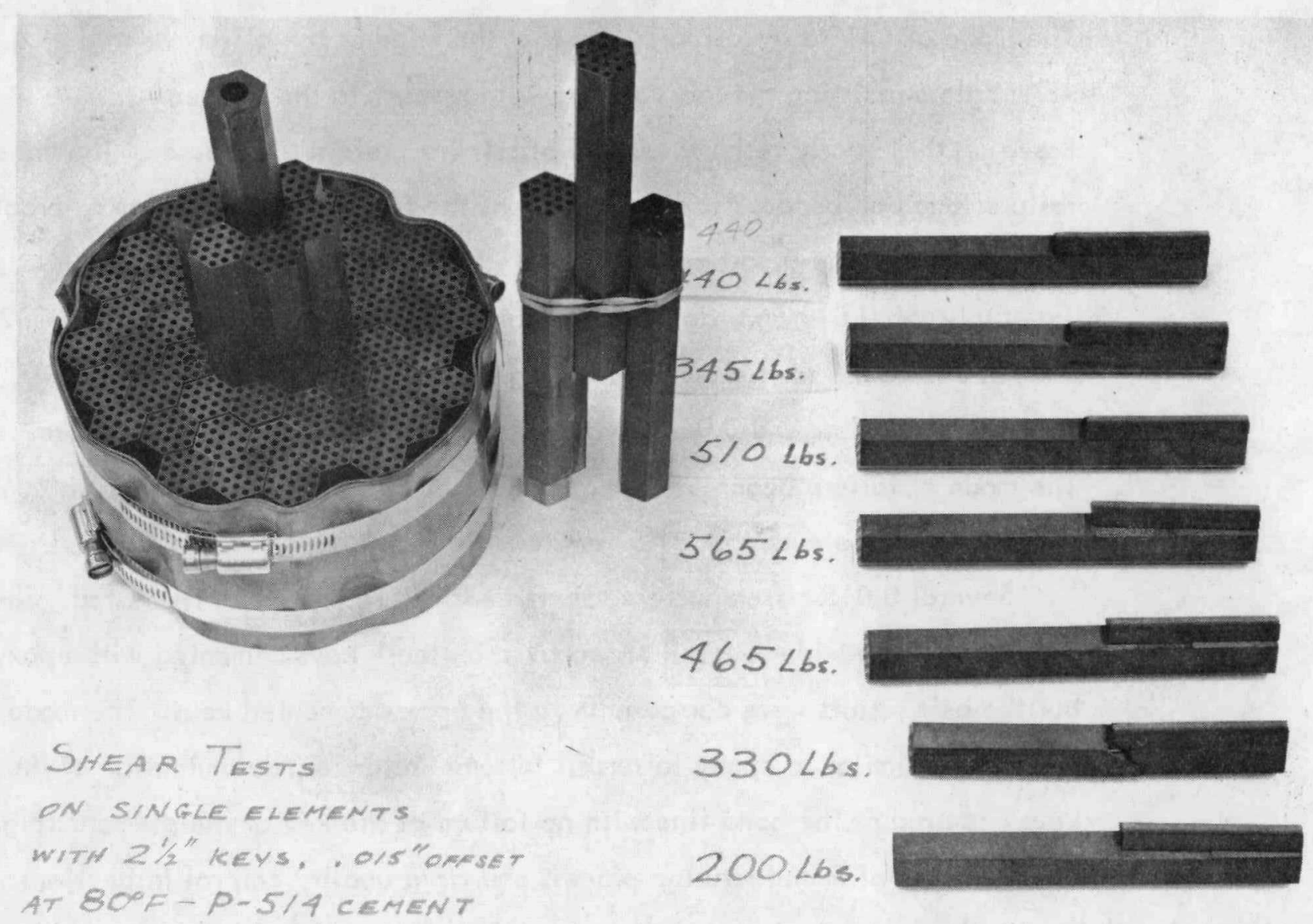

Shear Tests on Single Elements

Figure 14

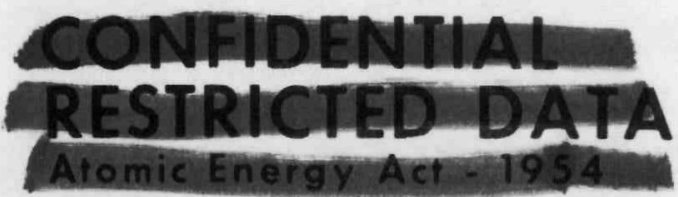


Several tests were conducted to determine the best thread size and fit in threaded designs. The specimens were simple 3 -inch lengths of graphite elements with female threads in the center of each end. Typical average values for thread failures were:

$\begin{array}{ll}\frac{T h r e a d}{\text { Thize }} & \text { Failure Load } \\ 7 / 16-14 & 619 \mathrm{lbs} . \\ 7 / 16-20 & 652 \mathrm{lbs} . \\ 3 / 8-16 & 603 \mathrm{lbs} . \\ 3 / 8-24 & 611 \mathrm{lbs} .\end{array}$

The mode of failure for these specimens was not in the threaded section but was a tensile failure across the element at the end of the male adaptor. These failures are graphically illustrated in Figure 15. To optimize the design, smaller diameter threads were tested in an attempt to precipitate failures in the threads and/or obtain greater strength. Threads of 5/16 - 18 and 5/16 -24 were tested to average failure loads of $681 \mathrm{lbs}$. The mode of failure was again a tensile failure across the element.

Hollow threaded tie rod designs were also tested to an average failure load of 751 lbs. The results were quite consistent and ranged from a low of 680 lbs. to a high of 845 lbs. The design objective for these threads was 612 lbs.

Stainless steel interlocking pins with diameters of $.060, .070$, and .090 have been room temperature tested. The tests showed there is very little effect of diameter and mode of failure is identical in all cases. Failure occured by a piling action when the pin elongated the groove and crumbled the graphite material during relation motion (Figure 16 and Figure 17 ). This resulted in a buildup of powdered graphite material head of the pin and erratic load levels as movement progressed. Figure 18 is a plot of the load vs. displacement curves. The average loads obtained were:

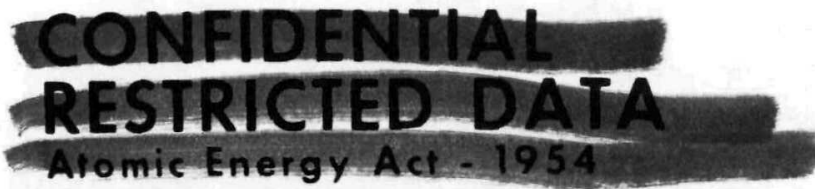



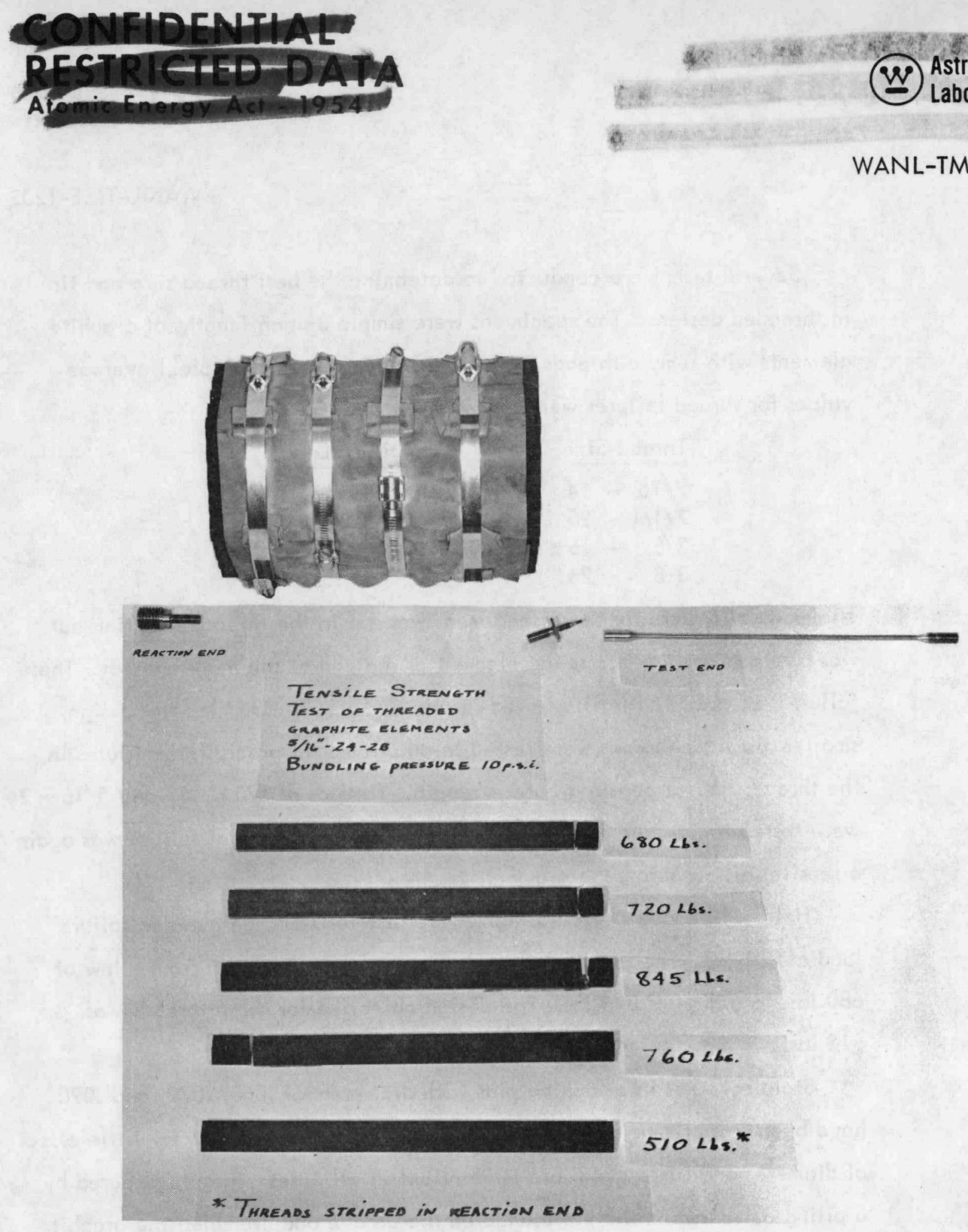

Threads strippeo in meaction END

Tensile Strength Test of Threaded Graphite Elements

Figure 15

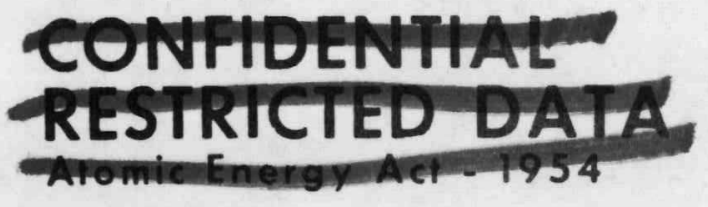




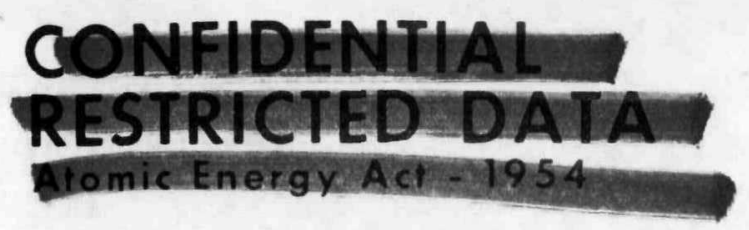

(W) Astronucleat

WANL-TME-1202

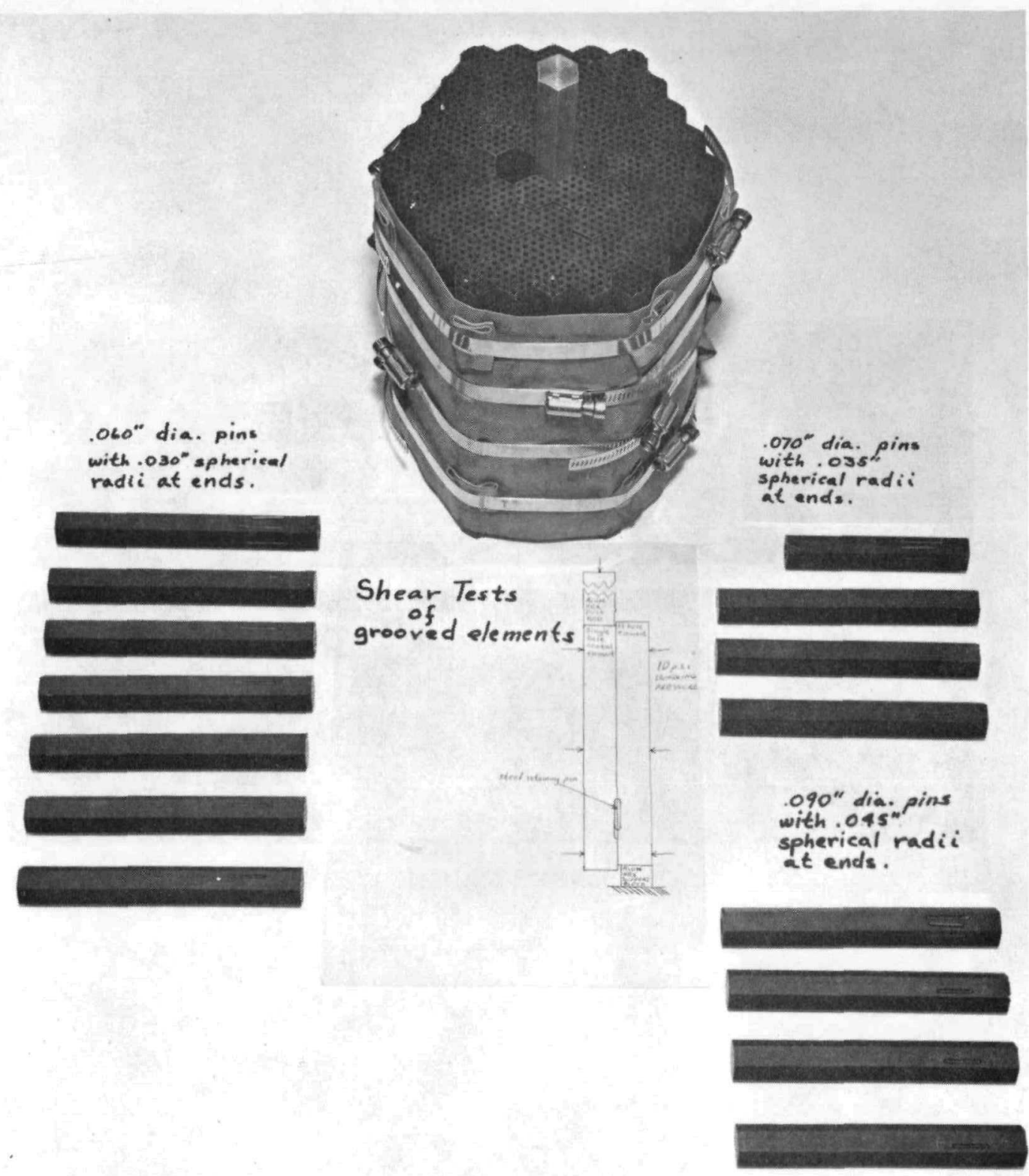

Apparatus used in Testing Shear Strength of Element Pin Interlock System

Figure 16
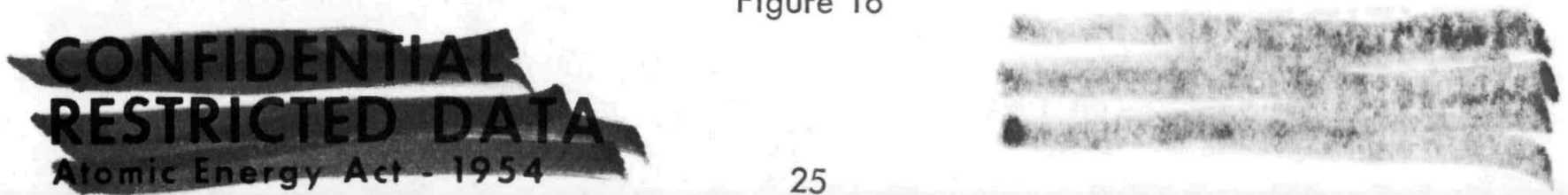

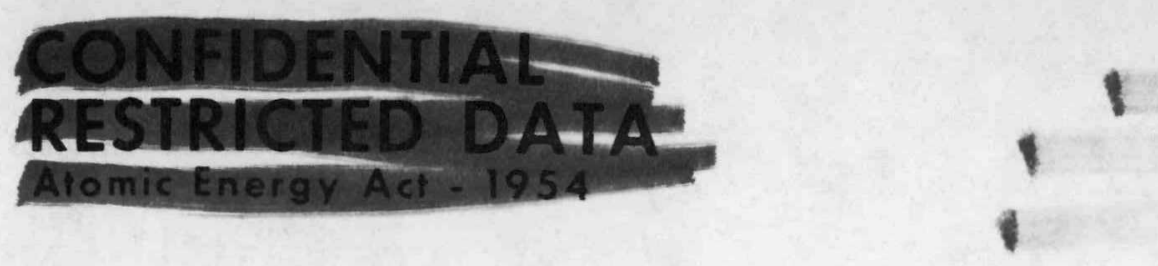

(w) Astronuclear

(W) Laboratory

WANL-TME-1202
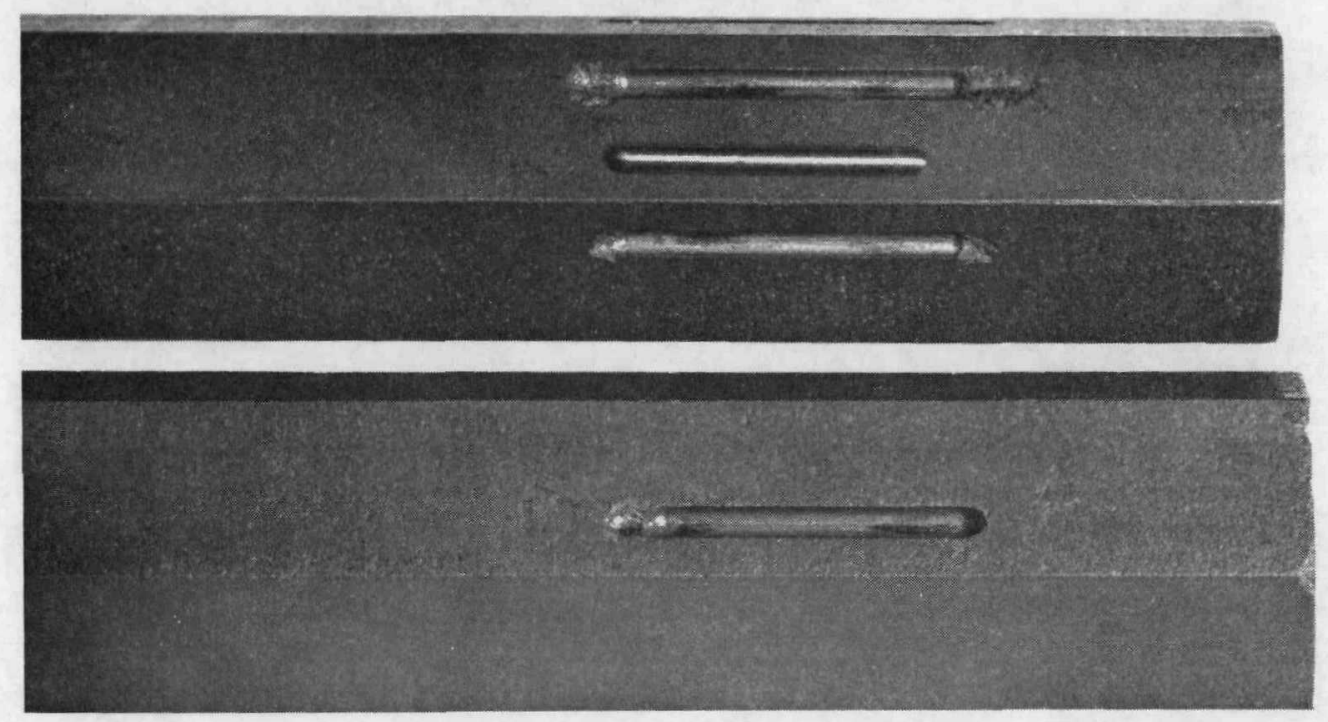

.070" Diameter Pins

Figure 17
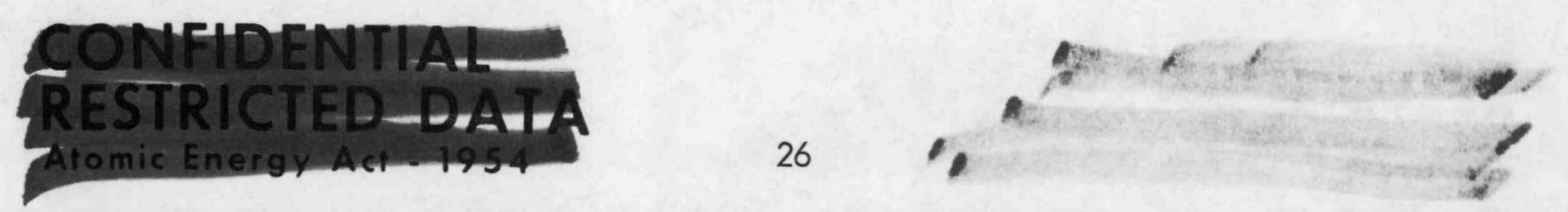


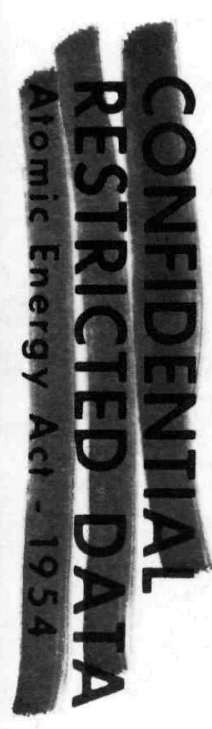

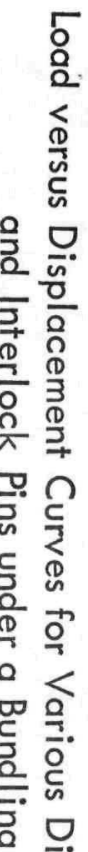

\begin{tabular}{|lll|l|l|l|l|l|l|}
\hline \\
\hline
\end{tabular}

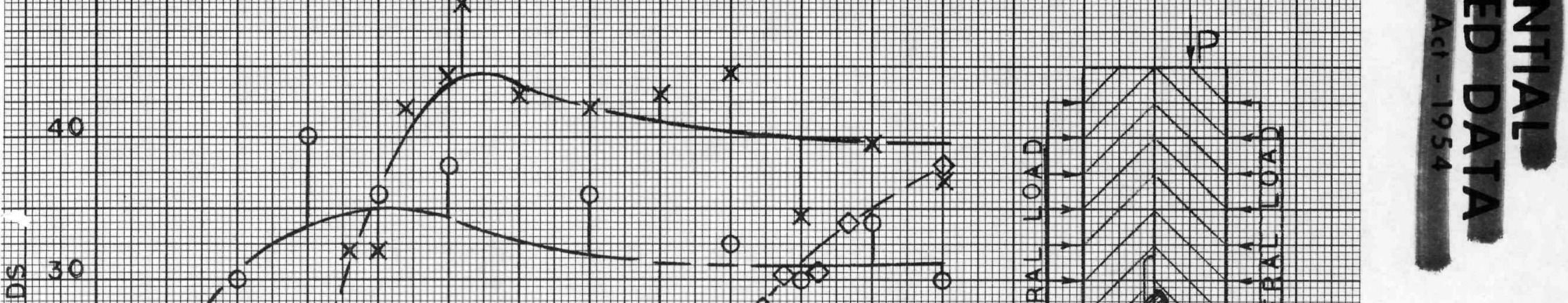

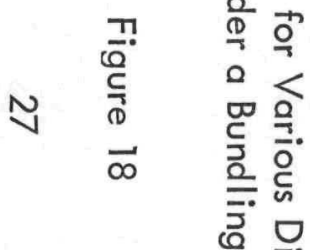

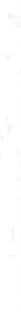

$+1 . \frac{2}{2}$

옹 욲

요

항.
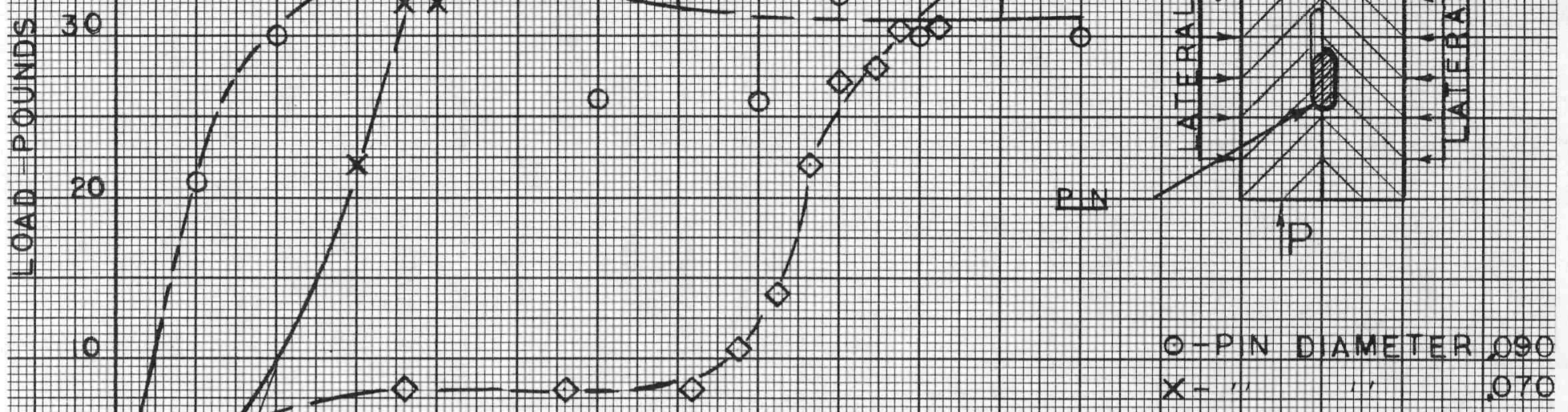

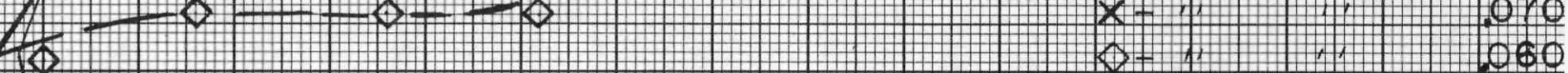

잉
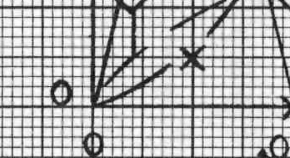

T)

。

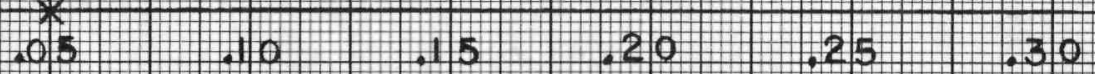

$\frac{m}{10}$
3
$\frac{0}{3}$
$\stackrel{5}{4}$

\section{DISPE-ACEMENT- NCHES}
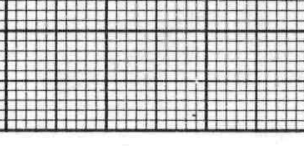
WANL-TME-1202

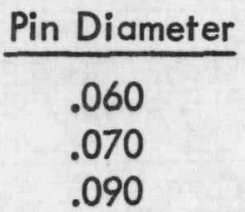

Failure Load

26 lbs.

34 lbs.

36 lbs.

The .070 diameter was selected for the design primarily because the fit of the groove between the element flow channels was better than that for the .090 diameter pin. All of the pins tested had spherical ends. The mode of failure through plowing action lead to an investigation of pins with squared-off ends. These pins are expected to yield higher loads and should approach the design goal of 65 lbs.

EML-73 Inner Reflector Testing

Tests were performed on six small scale graphite barrels to compare their critical buckling pressures in two additional modes of failure. These new modes resulted from two test configurations. In the first of these the inward displacement was restrained by an internal plug 80 mils smaller in diameter than the inside diameter of the graphite barrels, and the outward displacement at the ends of the barrels was restrained by external collars 16 mils larger in diameter than the outside diameter of the barrels. In the second configuration no radial restraints were imposed on the barrels.

All the barrels tested exceeded their calculated design requirements, thus satisfactorily demonstrating the ability of both bonded and unbonded stave barrels to withstand their design pressures in the two additional modes tested. 


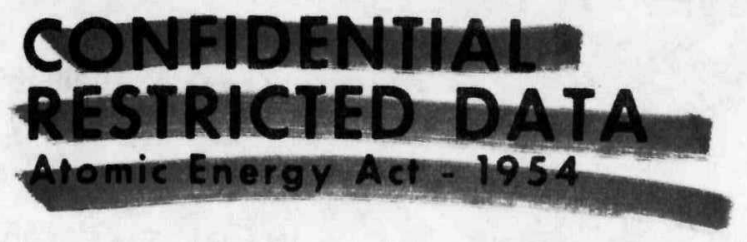

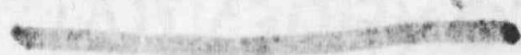

(2) Astronuclear

Laboratory.

WANL-TME-1202

EML-75 Friction Tests of Reactor Components

Tests of $\mathrm{NbC}$ coated fuel element wafer and support block specimens were performed with and without a TaC foil separator to determine the temperature at which bonding occurs. The test rig is schematically illustrated in Figure 19 . The tests were performed in hydrogen for 10 and 20 minutes duration at temperatures from 4500 to $4800^{\circ} \mathrm{R}$ at a contact pressure of $250 \mathrm{psi}$. TaC foil was found to be very effective in preventing bonding at the most severe conditions investigated. When no separator was used, bonding did occur in 10 minute tests at $4500^{\circ} \mathrm{R}$. Support block specimens with coated projections less than 0.001 inch high were tested in hydrogen to determine whether the projection would cause damage to the fuel element coating during the relative motions which occur during reactor operation. The specimens were subjected to three cycles in which they simultaneously displaced and heated to $4800^{\circ} \mathrm{R}$, held at that temperature for 10 minutes and then simultaneously cooled and retumed to their original relative position. No increase in friction force or damage to any of the specimens was observed. The only effect of the coating projections was to burnish the fuel element coating surface. This burnish mark appears on the upper specimen in Figure 20

Tests of peripheral core components were also performed at $4500^{\circ} \mathrm{R}$ to determine the coefficient of friction and rubbing surface wear that might occur in reactor operation. No increase in friction was measured during the test, and no damage of any kind to the specimen surfaces was observed in the post-test inspections. Figure No. 21 gives test conditions, specimens and equivalent coefficient of friction.

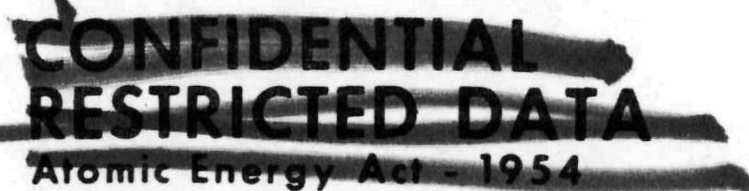




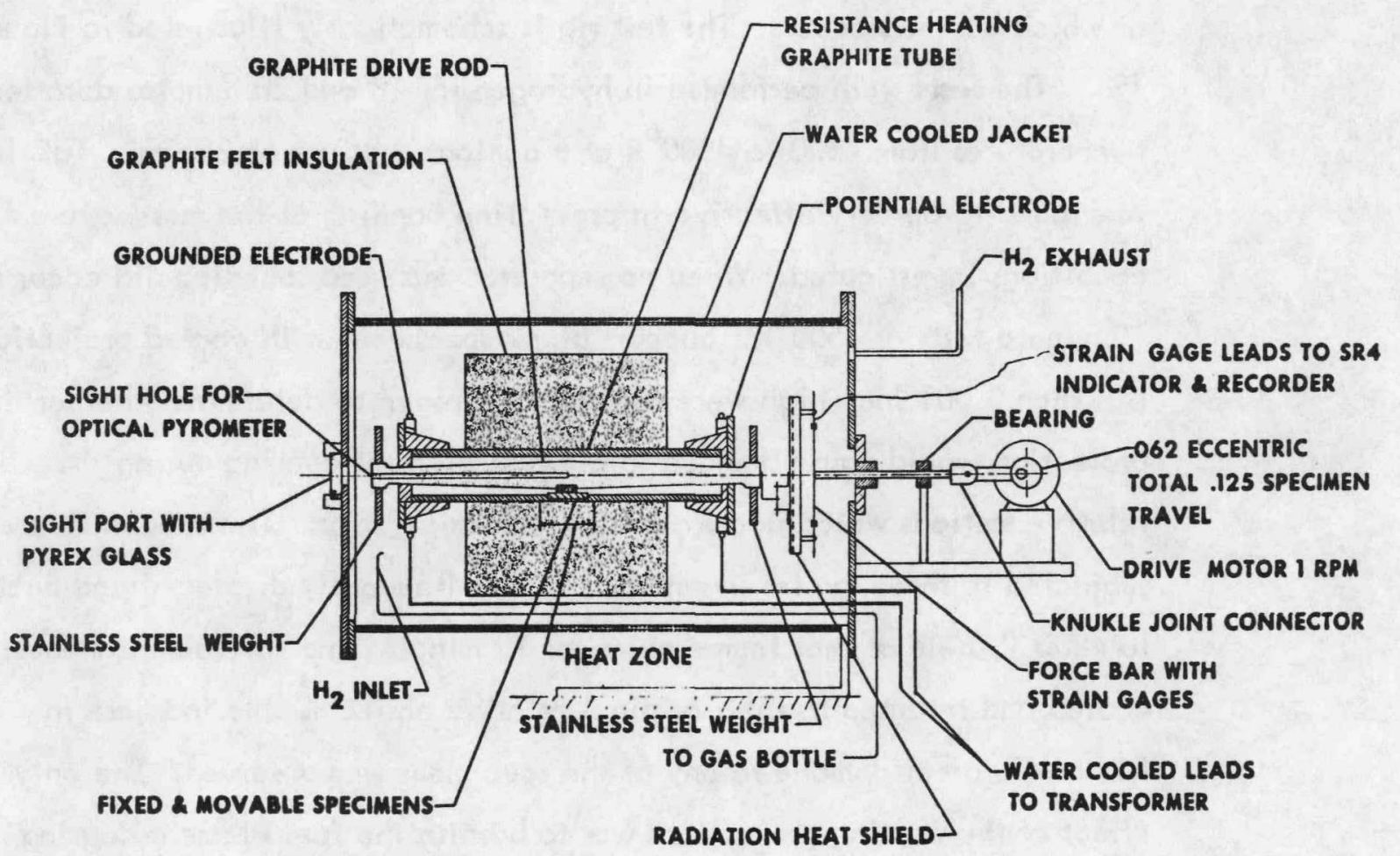

559722

Friction Test High Temperature Furnace

Figure 19

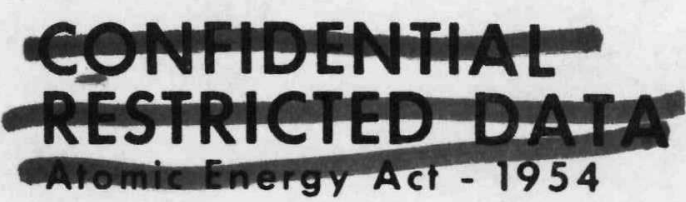



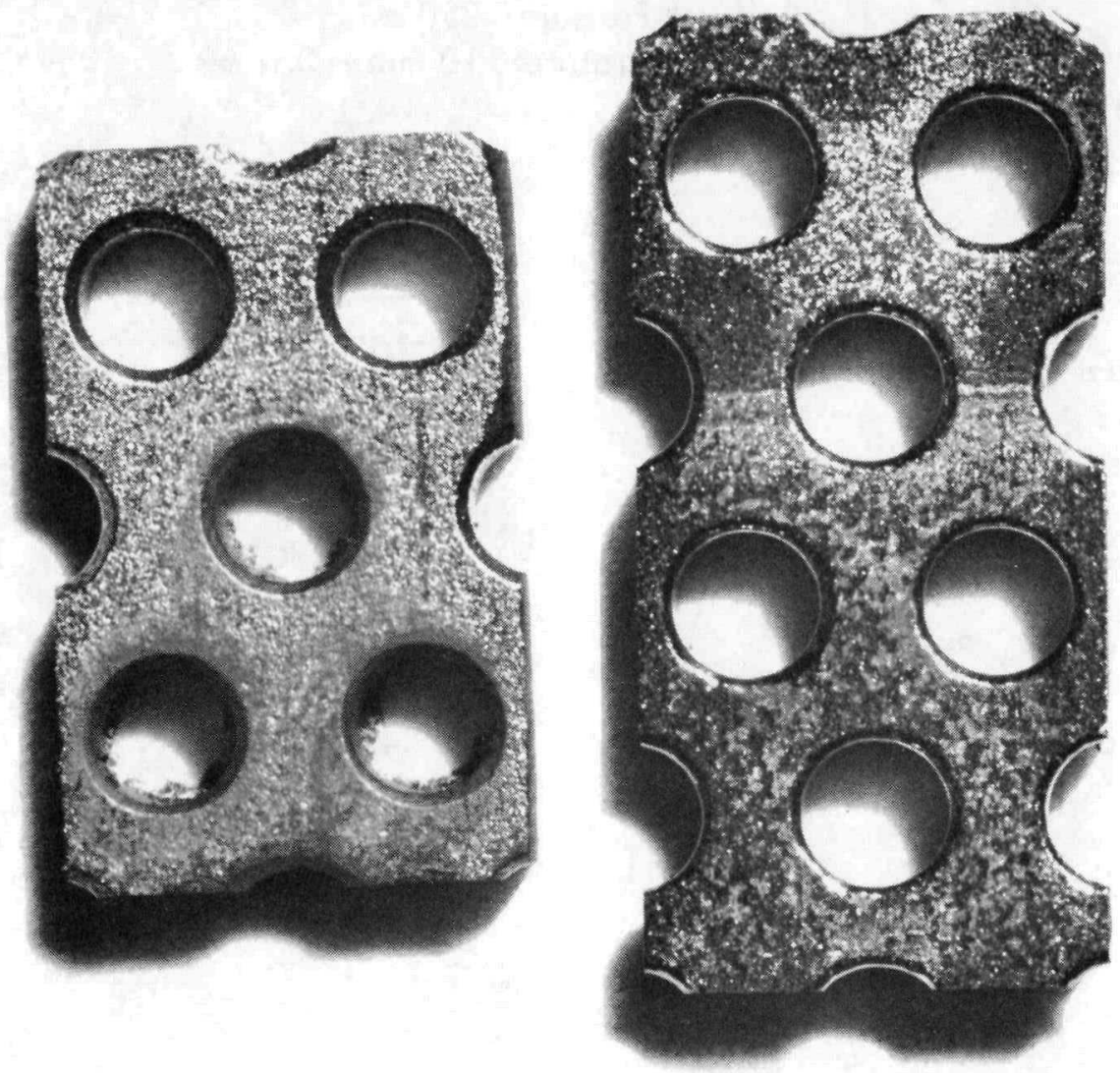

Fuel Element and Support Block Specimens after Friction Testing

Figure 20
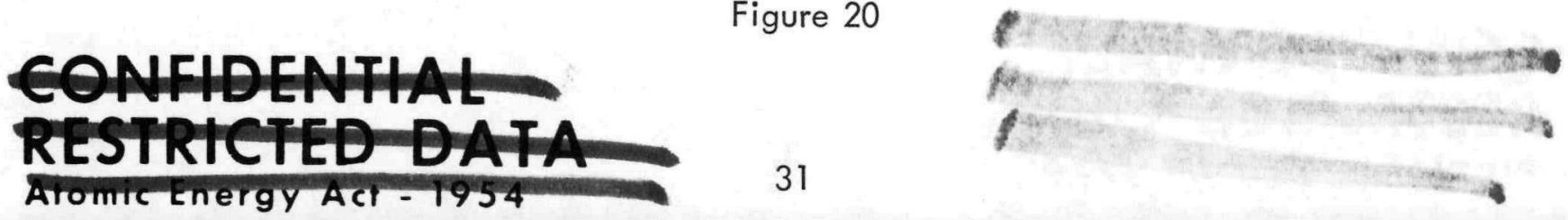
WANL-TME-1202

FRICTION TEST RESULTS

PERIPHERAL CORE COMPONENT INTERFACES

Test Temperature: $4500^{\circ} \mathrm{R}$

Contact Pressure: $250 \mathrm{psi}$

Time at Test Temperature: $10 \mathrm{~min}-3$ times

Interface

Coated Element - Coated Element

Coated Element - Uncoated Element

Coated Element - Uncoated Element

Coated Element - Pyrotile

Uncoated Element - Pyrotile

\author{
Maximum \\ Temperature
}

$4500^{\circ} \mathrm{R}$

$4500^{\circ} \mathrm{R}$

$3200^{\circ} \mathrm{R}$

$4500^{\circ} \mathrm{R}$

$4500^{\circ} \mathrm{R}$
Static Coefficient

of Friction

2.6

4.5

1.3

1.0

0.3

Friction Test Results

Peripheral Core Component Interfaces

Figure 21

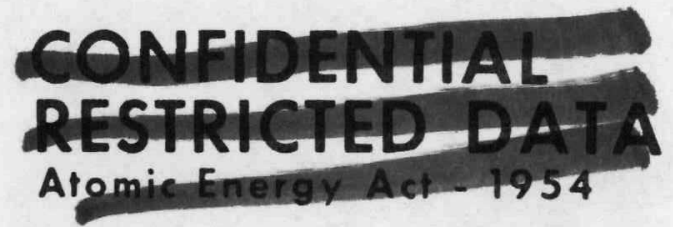


Mr. Kalvin asked if similar tests will be performed at higher temperatures. WANL representatives answered that no further testing is presently planned. The present tests have met the $4500^{\circ} \mathrm{R}$ peripheral temperature and elementsupport block temperature as seen in the NRX-A3 and A4 reactors. Mr. Kalvin asked if these tests had been to the limits of our furnace capability. WANL representatives replied that our existing furnaces could reach temperatures in excess of $5000^{\circ}$. However, some heater development work would be necessary before exceeding that temperature as the heaters might become ductile at these high temperatures. Mr. Kalvin enquired about the basic differences between EML-75 and EML-66. WANL representatives replied that EML-75 is a test which gives data during relative motion, and EML-66 is a static test.

EML-76 Reactor Hardware Static and Dynamic Tests

Preload stress and disassembly torque measurements were made on three instrument seal block and locknut assemblies. The test component is shown in Figure 22. The purpose of these tests was to determine the maximum preload stresses developed in the seal block at reactor operating temperature and whether disassembly of the block and locknut could be accomplished after three thermal cycles simulating reactor test runs. The maximum stress developed in the seal blocks varied from 25,800 to 39,800 psi at $140^{\circ} \mathrm{R}$ and 13,500 to 21,700 psi at $620^{\circ} \mathrm{R}$. These stresses are well below the yield strength of the material at these temperatures. Disassembly and reassembly of the parts was found to cause a 50 percent reduction in the stress variation. A third assembly disassembly cycle produced no further change in the results. The disassembly torque in all cases was less than the assembly torque.

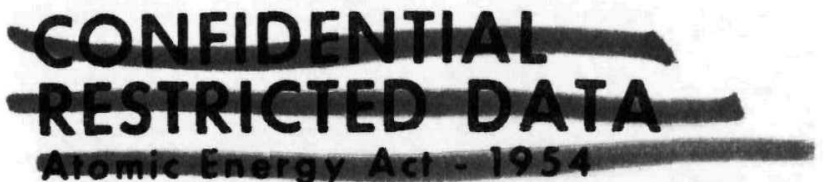



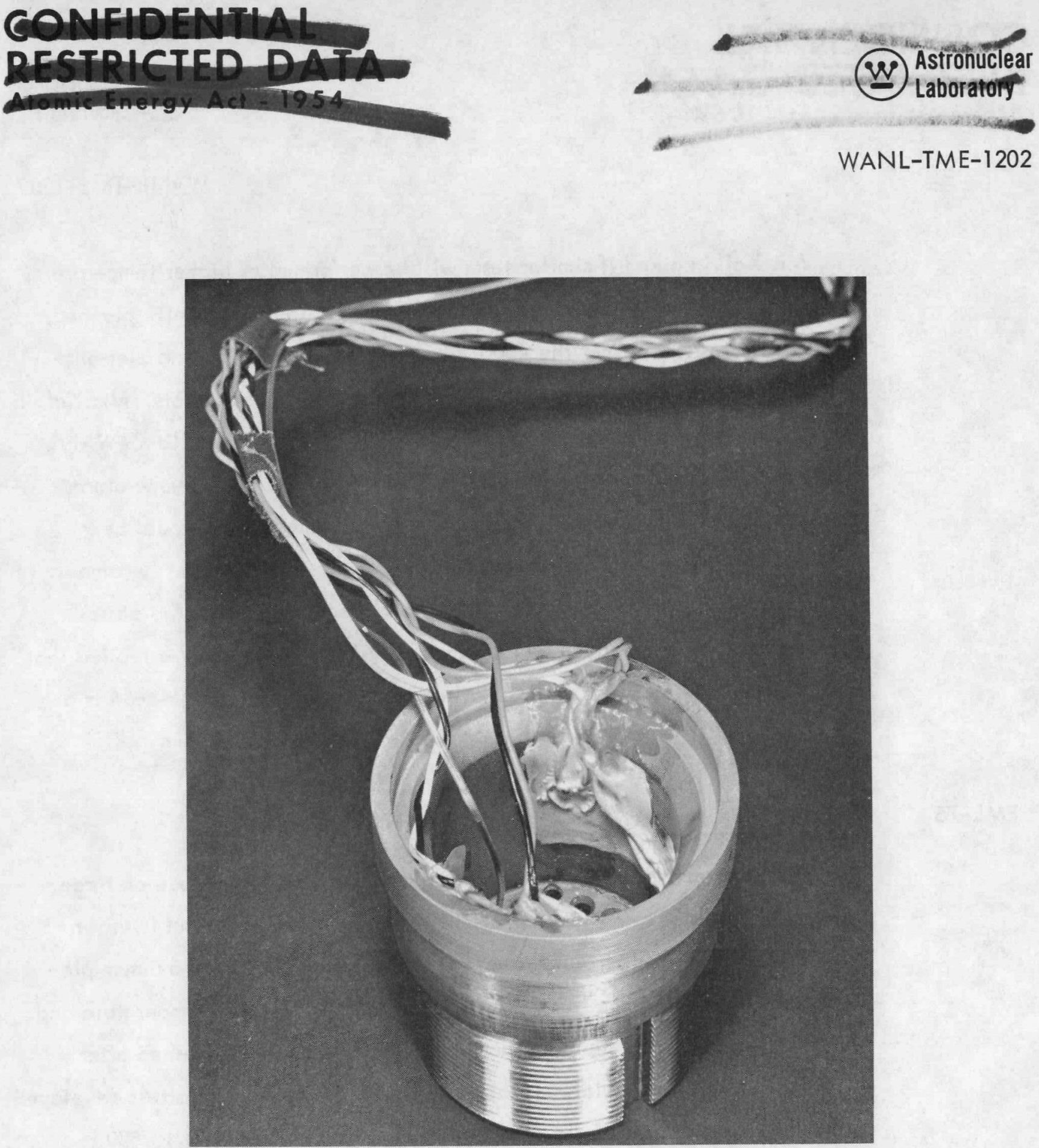

Instrumentation Seal Block

Figure 22

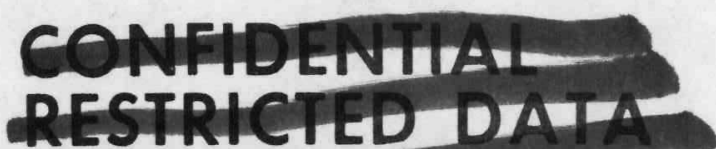


EML-82 Outer Reflector Sector Tests

A specimen of outer reflector sector material was tension-compression cycled between fixed strain limits. The strain conditions imposed were 0.105 percent in tension at $210^{\circ} \mathrm{R}$ and 0.108 percent in compression at $580^{\circ} \mathrm{R}$. The specimen was subjected to a total of 10 tension-compression cycles without failure. A full scale sector will be subjected to thermal strain testing during the month of August, 1965 to establish the strain actually developed during reactor startup conditions.

EML-92 Thermal Contact and Conductivity Properties

Thermal conductivity tests were performed on aluminum-graphite and beryllium-graphite combinations. The thermal conductivity of these combinations was found to increase as either temperature or interface contact pressure increases.

EML-93 Pyrofoil Wrapper Tests

Two tests were conducted to check the structural feasibility of a multilayer wrapper under simulated reactor strain conditions. The core was simulated by an aluminum ring on which a continuous wrap of pyrofoil was wound under constant tension. As in the proposed design, a row of filler strips distributed the lateral support pressure on the wrapper. Strain was induced in the wrapper by thermal expansion of the aluminum ring. During the first test, a 10 layer wrap of $10 \mathrm{mil}$ pyrofoil was expanded to 0.57 percent strain. In the second test, the wrapper was thermally expanded to 0.95 percent strain. In the first test, no actual breaks were produced in the wrapper but enough plastic straining had occurred to cause folding or buckling of the wrapper 


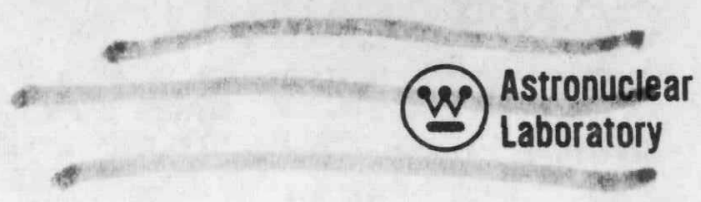

WANL-TME-1202

upon cooldown. In the second test complete separation of the wrapper occurred through all 10 layers. Additional tests are planned for the month of July. Filler strips will be placed on both the inside and outside of the foil to provide better distribution of pressure. Both 5 and 10 mil wrappers will be tested.

The following material was presented by the Fluid Flow Laboratory.

HHT-1

Quality Control Fuel Element Test

A total of 166 tests were performed since the last development review.

HHT-2 Single Element Process Development and Evaluation Test

During the past month, two tests were made with the three pin chuck. These tests, one for 50 minutes, one for 55 minutes, were made at $1 \mathrm{~B}$ conditions and were terminated by mid-band corrosion failure. In one of these tests, modified shielding was used at the hot end of the element. Results from this test indicated only a $100^{\circ}$ difference between the surface and internal temperature of the element. This shield has reduced radiation heat loss to a negligible amount. Additional tests have been made utilizing the new three pin chuck and the upstream loading cold end chuck. The test durations averaged 30 to 40 minutes. Due to the successful runs, these chucks will be recommended for quality control type testing. Mr. Kalvin requested that a written report concerning element temperature profiles in quality control testing be issued in the immediate future.

Starting June 1, a new temperature correction was introduced for elements tested in the Waltz Mills furnace. This correction was based on two independent calibrations made by two different groups. Both calibrations fell within one sigma of each other. Examination of early test data indicated 
a slow increase in power was required to maintain the same optic temperature. The calibrations performed on May 13 and 18 indicated a larger correction to the observed brightness was required to obtain the true temperature. Modification of prior test data to conform to the new calibration is now in progress. Mr. Kalvin stated he would like notice if instrumentation testing would interfere with development testing in the HHT-2 furnace. Mr. Kalvin asked how much of the hot end of the element is in a simulated reactor environment during an HHT-2 test. WANL representatives replied all of the support block and $1 / 2$ inch of the element. Mr. Larson asked if WANL was working on a scheme to better simulate interstitial corrosion. WANL representatives replied that they are.

HHT-5 Center Element Liner Corrosion Test

A series of tests were performed as a result of the turbo-pump cutoff during the NRX-A3 reactor tests. During this series of tests, two problems were investigated:

1. How much did the temperature transient damage the liner tube?

2. Would this damage impair reactor operation?

The results of these tests showed that even if the liner were completely removed for the last 14 inches on the hot end, corrosion in the center element would progress at approximately 8 mils per minute. This conclusion provided additional confidence in the ability of the NRX-A3 reactor to restart and run for at least 17 additional minutes. 


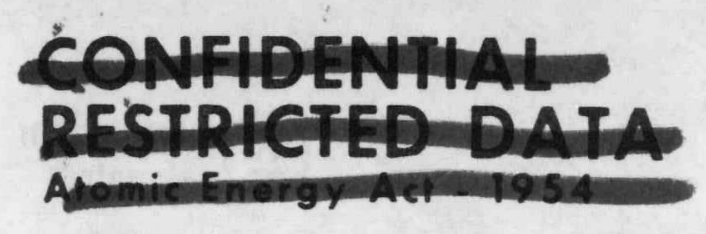

de

(2) Astronuclear

WANL-TME-1202

HHT-6 Interstitial Corrosion Test

The test configuration of a center hex element with a rod through the center bore has been fabricated and is ready to be installed in the furnace. High temperature will be supplied by an external radiant heater. All fixturing has been coated to eliminate the possibility of fixture corrosion. This test configuration will simulate a 5 mil interelement gap.

HHT-7 Filler Strip Corrosion Test

A heater development test was successful in taking a tapered heating element to a surface temperature of $5700^{\circ} \mathrm{R}$ and a calculated internal temperature of $6900^{\circ} \mathrm{R}$. These results are about 25 percent greater than the temperatures required for HHT-7 testing. The heating element failed at this temperature due to plasticity and internal sublimation.

HHT-16 Cavity Corrosion Test

Three tests were performed at temperatures of $3000^{\circ} \mathrm{R}$ and 20 minutes duration. The first test at 50 psi resulted in a weight loss of 0.013 grams. The second test was run at 150 psi with a weight loss of 0.06 grams. The third test was run at 300 psi and resulted in a 0.47 gram weight loss. The next series of tests will be run at $4000^{\circ} \mathrm{R}$. These tests are required to provide basic data for hot peripheral designs. 


\section{FFL-17 Modified Plugged Core Flow Test}

A series of tracer gas tests were successfully completed in which methane was injected at a controlled measure rate through probes at various core inlet locations and sampled through other probes downstream of the rejector. These samples were analyzed for methane content and the resulting concentrations plotted to give a generally well-defined tracer gas stream centerline location. Full details of all work completed to date are available in WANL-TME-1160. Mr. Kalvin asked if this data could be used to predict reactor flow. WANL representatives answered that it could in that cold flow data agrees with cold flow analytical calculations. Due to this agreement, we can assume more confidence in comparable hot flow calculations. Mr. Kalvin requested that WANL make a continuous comparison of this test and EML-60, "Core Effective Gap Test" to avoid duplication of effort. He was assured there was none.

This completed the Fluid Flow Laboratory presentation. Mr. Kalvin requested that the development test review meeting be omitted during the month of July and that a year end type review be held at an undertermined date late in July, 1965. The meeting then adjourned until 9:00 A.M., June 22, 1965 at which time a complete review of HHT-15, "Seven Cluster Thermal Test" would be held. 

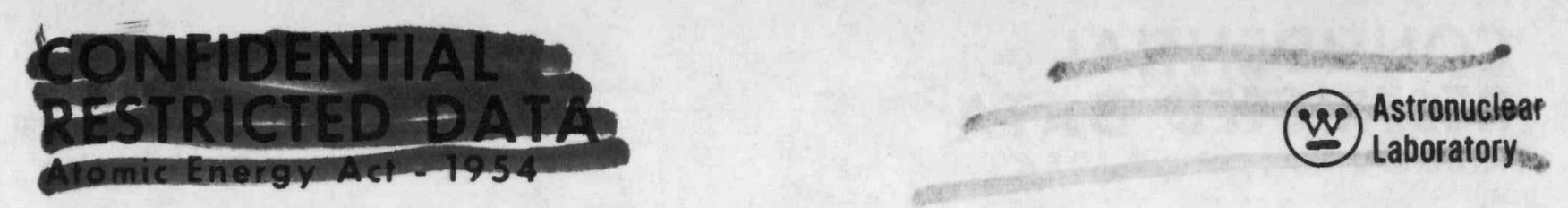

WANL-TME-1202

HHT-15 Seven Cluster Thermal Test

Attendees: Dr. E. A. DeZubay, Mr. L. Larson, Mr. G. Mader, Mr. G. Kalvin, Mr. H. Fix, Mr. F. D. Retallick, Mr. A. Selz, Mr. P. Zemanick, Mr. F. Kees

This discussion was opened by Dr. DeZubay stating that photographs of the NRX-A3 power test show evidence of interstitial corrosion. HHT-15 is the only test planned by WANL capable of investigating this type of corrosion problem. This test would also be a versatile development vehicle for candidate designs. The discussion can be summarized with these questions and answers.

Question: Will HHT-6, "Interstitial Corrosion Test" and HHT-7, "Filler Strip Corrosion Test" supply the same information as HHT-15?

WANL

Answer: $\quad$ No - in that neither HHT-6 or HHT-7 call for a sufficiently large core to provide the required flow through a large number of interstitial passages. HHT-7 is an investigation of peripheral gap corrosion.

Question: Will HHT-15 provide both axial and radial flow?

WANL

Answer: Yes, other tests do not. HHT-15 type of core is the only configuration capable of providing a sufficient number of gaps and axial and radial flow.

Question: What is the expected test life of this type of test core?

WANL

Answer: The test life of the core is dependent upon the life of the heater at $6000^{\circ} \mathrm{R}$. However, this configuration has been designed to permit rapid changing of heaters. 
Question: What is the approximate hardware cost for each build of this configuration?

WANL

Answer:

About $\$ 75,000$ for the first build and $\$ 50,000$ for each subsequent build.

Question: What piping modifications are required before testing can commence?

WANL

Answer:

An extension of the loop in WANHES Test Cell would be used, with relatively simple conversion.

Question: What is the approximate cost of instrumentation and recording equipment modifications required for this test?

WANL

Answer:

Approximately $\$ 100,000$ including patchboards, leads from control room to test cell and labor.

Mr. Kalvin suggested that work continue on this test with these conditions:

1. A test description is to be immediately written and published.

2. That a series of hold points be established. The hold points appear in the following diagram: 

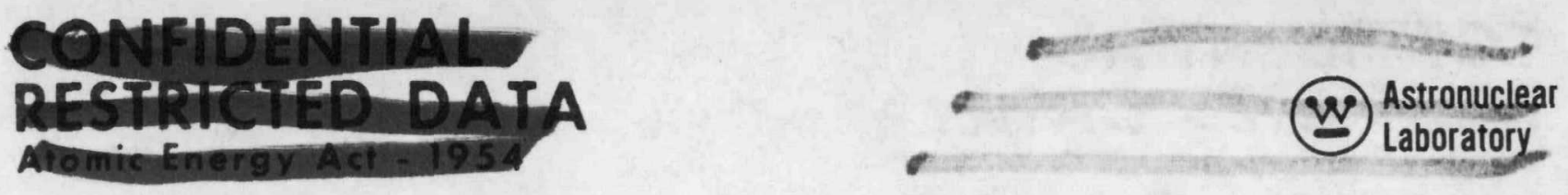

WANL-TME-1202

Procure hardware quotes and forward through normal channels. None to be released to supplier.

Accomplish heater development program.

Release long lead procurement items (basically graphite that could be used elsewhere).

Technical evaluation - look at KIWI 321 test and $\mathrm{A} 3$ post-mortem or any other $\mathrm{HHT}$ test that would effect HHT-15.

Technical hold - justification review of HHT-15 - Review build no. I configuration.

1. Release short-term procurement items.

2. Installation of piping and wiring.

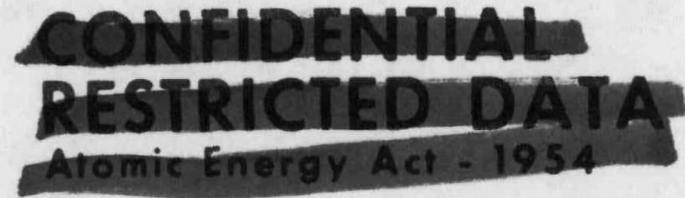


The following is a tabulation of activity on test numbers as they are described in WANL-TME-1034:

\begin{tabular}{|c|c|c|}
\hline $\begin{array}{l}\text { Test } \\
\text { No. }\end{array}$ & $\begin{array}{c}\text { Test } \\
\text { Activity } \\
\end{array}$ & $\begin{array}{l}\text { Test } \\
\text { No. } \\
\end{array}$ \\
\hline HHT-I & See this report & EML-68 \\
\hline 2 & See this report & 69 \\
\hline 4 & See this report & 70 \\
\hline 6 & See this report & 72 \\
\hline 7 & See this report & 73 \\
\hline 11 & Indefinitely postponed & 74 \\
\hline 13 & No activity & 75 \\
\hline 15 & See this report & 76 \\
\hline 16 & See this report & 77 \\
\hline FFL-6 & Yes & 79 \\
\hline 15 & Yes & 82 \\
\hline 17 & See this report & 85 \\
\hline 18 & Yes & 86 \\
\hline 19 & No activity & 87 \\
\hline 20 & No activity & 88 \\
\hline 21 & Yes & 89 \\
\hline$E M L-41$ & No activity & 93 \\
\hline 60 & See this report & \\
\hline 61 & See this report & \\
\hline 62 & No activity & \\
\hline 63 & No activity & \\
\hline 64 & No activity & \\
\hline 65 & See this report & \\
\hline 66 & See this report & \\
\hline 67 & See this report & \\
\hline
\end{tabular}

Test

Activity

See this report See this report See this report No activity See this report No activity See this report See this report No activity No activity No activity See this report See this report No activity Completed Yes Completed See this report See this report 